Western\&Graduate\&PostdoctoralStudies

Western University

Scholarship@Western

Electronic Thesis and Dissertation Repository

10-19-2017 1:00 PM

\title{
A Simulated Walk in Nature: Testing Predictions from the Attention Restoration Theory
}

Corey Crossan, The University of Western Ontario

Supervisor: Dr. Alan Salmoni, The University of Western Ontario

A thesis submitted in partial fulfillment of the requirements for the Master of Arts degree in

Kinesiology

(C) Corey Crossan 2017

Follow this and additional works at: https://ir.lib.uwo.ca/etd

Part of the Alternative and Complementary Medicine Commons, Cognitive Psychology Commons, Exercise Science Commons, Health Psychology Commons, Landscape Architecture Commons, and the Psychology of Movement Commons

\section{Recommended Citation}

Crossan, Corey, "A Simulated Walk in Nature: Testing Predictions from the Attention Restoration Theory" (2017). Electronic Thesis and Dissertation Repository. 4998.

https://ir.lib.uwo.ca/etd/4998

This Dissertation/Thesis is brought to you for free and open access by Scholarship@Western. It has been accepted for inclusion in Electronic Thesis and Dissertation Repository by an authorized administrator of Scholarship@Western. For more information, please contact wlswadmin@uwo.ca. 


\begin{abstract}
Attention Restoration Theory (ART) predicts that top-down processing during everyday activities can cause attentional fatigue and that bottom-up processing that occurs when people experience nature will be restorative (Kaplan, 1995). The present study examined this prediction by exposing participants to three different conditions using a repeated measures design: a control condition during which participants walked on a typical treadmill, a nature/restorative condition during which participants walked on the same treadmill, experiencing a simulated nature walk, and a perturbation condition that included the same simulated nature scene but also required top-down processing during the walk. The findings supported ART predictions. As measured by the backwards digit span test, the nature condition produced a significant improvement in directed attention performance compared to the control and perturbation conditions that did not. Natural or simulated natural environments could be implemented throughout University campuses to support a more effective learning environment for students.
\end{abstract}

Keywords: Attention Restoration Theory, Directed Attention, Nature, Top-down Processing, Bottom-up Processing, Attentional Demands, Directed Attention Fatigue, Restore, Physical Activity, Mental Concentration 


\section{Co-Authorship}

The author, under the supervision and mentorship of Dr. Alan Salmoni, conducted the work in this master's thesis. With the guidance of Dr. Alan Salmoni, I designed the experiment and collected, analyzed, interpreted all of the data, and prepared the manuscript. For this manuscript, Corey Crossan was the first author and Dr. Alan Salmoni served as a co-author. 


\section{Acknowledgements}

I would like to express my greatest appreciation to my graduate supervisor, Dr. Alan Salmoni. Dr. Salmoni provided a welcoming entrance into the program with an openmind, eager to assist my research interests. Dr. Salmoni provided great guidance by ensuring I had a strong foundation in research before diving into the creation of my thesis study. I am thankful for his weekly Journal Club activity that teaches his students to critically analyze studies across several different fields. I am also grateful for his patience in helping me fine-tune my thesis study and lastly for his continuous availability to meet and provide feedback in bringing this thesis to its completion.

I would like to thank Dr. Christopher Lee who taught a Quantitative Research Methods class that I took early in my Master's degree. I sought his help for some statistical support in my thesis and he was very welcoming and happy to help - his assistance is greatly appreciated. I would also like to thank all of my professors who helped elevate my capacity to think and write more critically.

I would like to thank all of Dr. Salmoni's graduate students for being there when I needed help or guidance. I would also like to thank them for gathering at Journal Club every week and putting forward their best effort when analyzing each study. I have learned so much from each student's analysis expertise.

I would like to thank all of the participants who engaged in this study. It is with their commitment to participate that I was able to collect the data and write my Master's thesis. A special thanks to the Wolf Lab and the members of the lab that allowed and helped me to use their equipment. There would have been no possible way for me to complete this study without their help.

A big thanks to my family, friends and schoolmates who continued to support, encourage, and push me through this process. I am very thankful to all of you who listened to my struggles and my excitement, and to those who would simply discussed ideas with me. I am so grateful for this experience and I would not have been able to have had this opportunity without each of the aforementioned people. A sincere thanks to all of you. 


\section{Table of Contents}

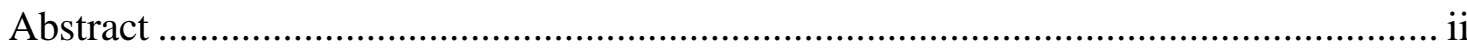

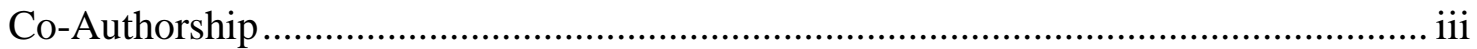

Acknowledgements ................................................................................................ iv

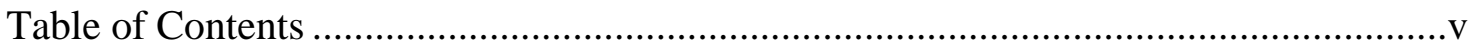

List of Abbreviations...................................................................................... vi

List of Tables..................................................................................................... vii

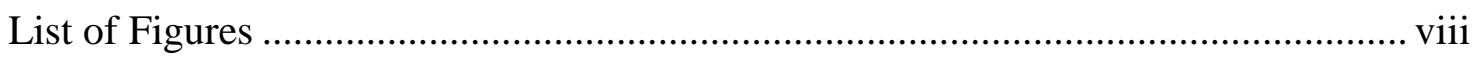

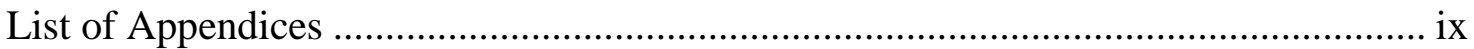

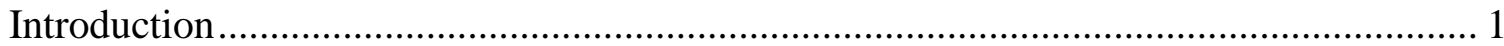

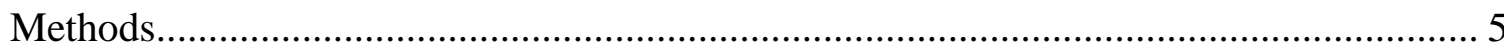

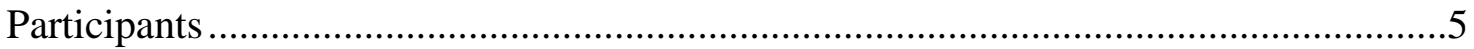

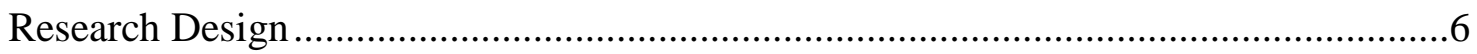

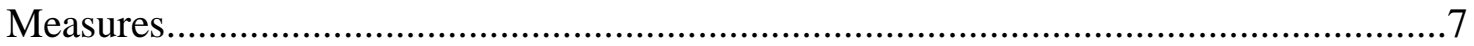

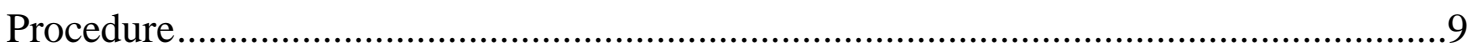

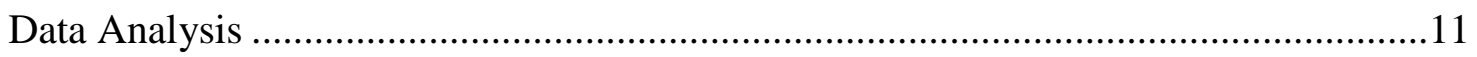

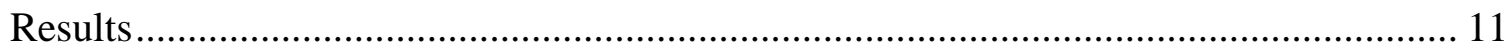

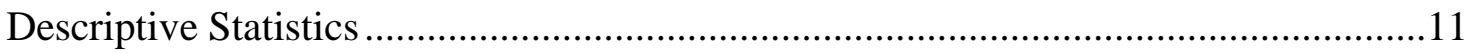

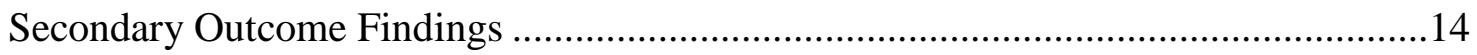

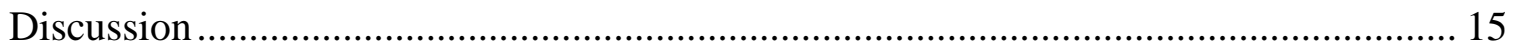

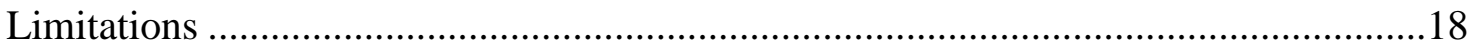

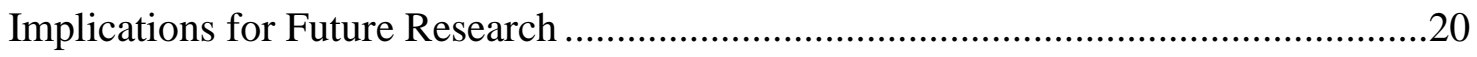

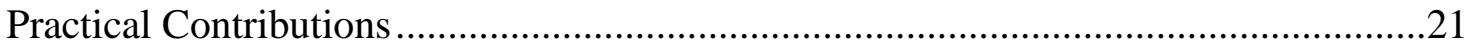

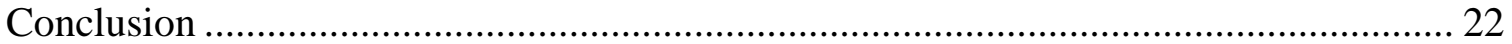

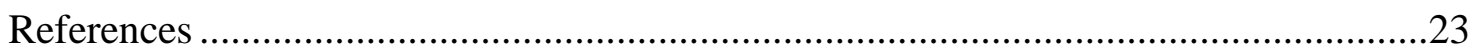

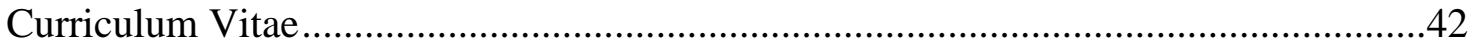


List of Abbreviations

ART

$\mathrm{CC}$

DSB

DSF

$\mathrm{NC}$

NCT

PANAS

PC

SART

SDMT

SMT

SST

ST

TMTA

TMTB
Attention Restoration Theory

Control Condition

Digit span backwards

Digit span forwards

Nature Condition

Necker cube test

Positive Affect Negative Affect Scale

Perturbation Condition

Sustained attention to response test

Symbol digit modalities test

Search and memory task

Symbol substitution test

Stroop task

Trail making test A

Trail making test $\mathrm{B}$ 


\section{List of Tables}

Table 1. Condition Participation Order............................................................... 9

Table 2. Session Testing Order and Duration for Each Segment .................................. 10

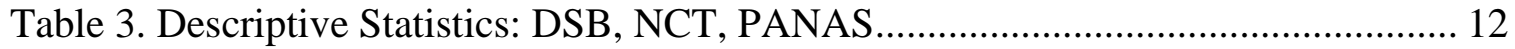




\section{List of Figures}

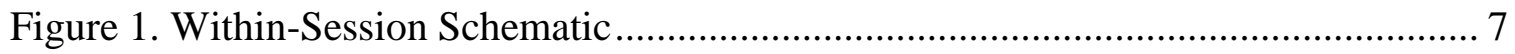

Figure 2. Performance on the Backwards Digit Span Test ......................................... 13

Figure 3. Performance on the Necker Cube Test ....................................................... 14

Figure 4. PANAS Positive Mood Scores ............................................................... 15 


\section{List of Appendices}

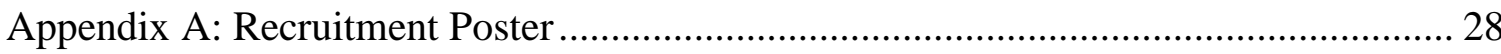

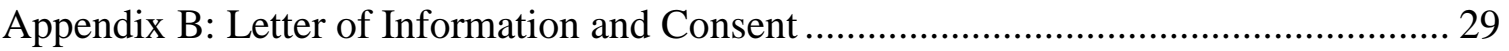

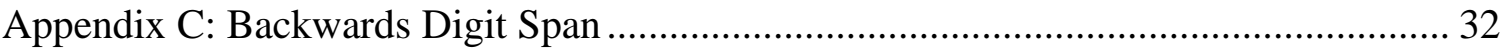

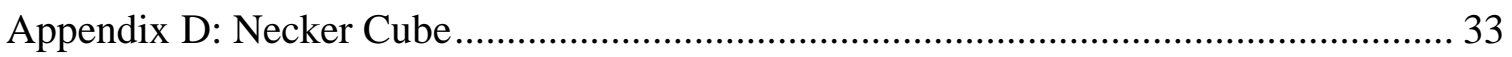

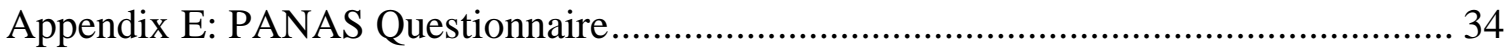

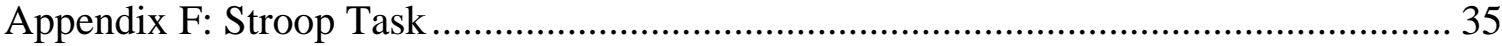

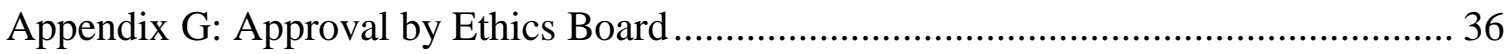

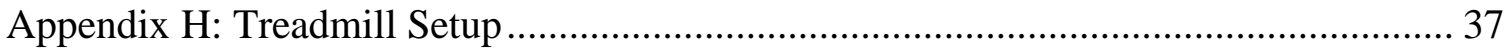

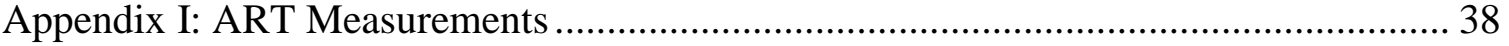

Appendix J: Characteristics of included ART Studies .............................................. 39 


\section{Introduction}

University students are often required to focus their attention throughout a typical school day. The ability of an individual to focus one's attention toward a specific task is known as directed attention. Directed attention is voluntary, requiring the individual to focus on a specific task while suppressing distractions that may be more interesting to the individual (Kaplan, 1995; Kaplan \& Berman, 2010). Because directed attention requires effort, directed attention fatigue may occur (Kaplan, 1985; 1989). Directed attention fatigue can have serious negative consequences such as poorer decision-making and lower levels of self-control (Fan \& Jin 2013; Hare, Camerer \& Rangel, 2009; Vohs, Baumeister, Schmeichel, Twenge, Nelson \& Tice, 2008). Fatigue is not conducive to an effective learning environment, therefore it is important to understand how to restore directed attention.

Attention Restoration Theory (ART) proposes that natural environments are generally restorative to directed attention because they require a different type of attentional processing compared to the typical, attentionally demanding environments most individuals must participate in daily. Berman, Jonides and Kaplan (2008) described that over half of the world's population live in an urban environment and from a psychological perspective, urban environments impose high demands on cognitive functions. Urban environments require the individual to process information in a topdown manner, generally derived from focused task demands and capture attention dramatically, requiring the use of directed attention (Kaplan, 1995). On the other hand, natural environments can simply require bottom-up processing, modestly grabbing an individual's attention without effort, allowing directed attention time to rest and restore (Kaplan, 1995; Muschman \& Miller, 2007). The importance of measuring directed attention in ART research stems from the desire to understand how to restore directed attention when it has become fatigued.

ART studies are generally focused on measuring an environment's capacity to restore directed attention. A typical ART study exposes participants to different environmental conditions with different predicted levels of "restorativeness" for directed attention. 
Exposure durations have varied across studies ranging from as little as seven minutes and up to three months. In addition, several different measures (DSB; DSF; Proofreading; SMT; SART; SDMT; SST; TMTA; TMTB; NCT) have been used to measure an environment's restorative effects (Appendix I). The present study compared three different environmental conditions with a short, ten-minute exposure time. The backwards digit span test (DSB) and the Necker cube test (NCT) were used to measure directed attention performance.

Various natural environments have been studied in the ART literature, including: parks (Berman et al., 2008; Berman, Kross, Krpan, Askren, Burson, Deldin, Kaplan, Sherdell, Gotlib, \& Jonides, 2012; Bodin \& Hartig, 2003; Hartig, Mang \& Evans, 1991; Johansson, Hartig, \& Staats, 2011; Shin, Shin, Yeoun \& Kim, 2011; Taylor \& Kuo, 2009), forested/tree environments (Hartig, Book, Garvill, Olsson \& Garling, 1996; Mayer, McPherson Frantz, Bruehlman-Senecal \& Dolliver, 2009; Perkins, Searight \& Ratwik, 2011; Rich, 2008; van den Berg \& van den Berg, 2011), the wilderness (Hartig et al., 1991), terrace and garden environments (Ottosson \& Grahn, 2005) and vegetation environments (Kuo, 2001). Furthermore, ART studies have used various forms of participation in nature such as: physically active engagement, normally walking (Berman et al., 2008, Berman et al., 2012; Bodin \& Hartig, 2003; Cimprich \& 2003; Hartig et al., 1991; Hartig et al., 1996; Johansson et al., 2011; Mayer et al., 2009; Perkins et al., 2011; Shin et al., 2011; Stark 2003; Taylor \& Kuo, 2009) and passive engagement such as sitting (Kuo 2001; Otosson and Grahn, 2005; Rich 2008; Taylor, Kuo and Sullivan 2002; Tennessen and Cimprich, 1995). Not only has participation varied but the exposure medium has also varied. For example, studies have had participants view photos of nature (Berman et al., 2008; Berto 2005; Chen, Lai \& Wu, 2011; Hartig et al., 1996; Laumann, Gärling \& Stormark, 2003; Rich 2008; van den Berg, Koole \& Van Der Wulp, 2003), watch videos (Hartig et al., 1996; Laumann et al., 2003; van den Berg et al., 2003) and experience artificial plants indoors (Rich, 2008). Berman et al. (2008) conducted two experiments. The first compared a walk through a park (nature) with a walk downtown (urban) and the second, compared the effects of viewing photos of nature with photos of urban settings. Both experiments found the natural (actual nature or photos) environments to be more restorative compared to the urban environments. Importantly for the present 
research is the fact that both authentically natural settings and depictions of natural settings have been effective in restoring directed attention.

Not only have ART studies exposed participants to authentically natural and depictions of natural environments, but exposure duration to these environments has also varied across studies. Cimprich $(1992 ; 1993)$ studied the effects of three months of exposure for recovering cancer patients. On the other end of the spectrum, studies have used exposure durations from ten minutes (Mayer et al., 2009; van den Berg et al., 2003) to forty minutes (Hartig et al 1991; Berman et al., 2008). In between the extremes, Hartig et al. (1991) studied the effects of a four to seven day exposure time. Barton and Pretty (2010) studied different doses of acute exposure to green exercise required to improve mental health. Although not directly studying ART, they found that a five-minute exposure to green exercise had the largest impact on positive self-esteem and mood. In summary, the study by Mayer et al. (2009) found that a ten-minute exposure time to a natural environment improved attention and Berman et al.'s (2008) second experiment found restorative effects from a ten-minute exposure time of viewing images of natural environments. Short exposure durations were of particular interest for the present research as they mimic between-class breaks often experienced by university students.

The variable of main concern when comparing different environmental conditions in ART research is whether the environment requires an individual's bottom-up or topdown processing and the associated effects on directed attention. The Berman et al. (2008) study attempted to compare these types of information processing by comparing a natural environment (bottom-up processing) to an urban environment (top-down processing). Berman predicted that the natural environment would induce bottom-up processing by naturally captivating the individual's attention. In comparison, he predicted the urban environment would induce top-down processing by forcing the participants to process expected and unexpected stimuli necessary, for example, when avoiding a car or collision with another pedestrian. Many studies have compared the restorative effects of exposure to natural (bottom-up) and urban (top-down) environments (Bodin \& Hartig, 2003; Cimprich \& Ronis, 2003; Hartig et al., 1991; Hartig et al., 1996; Johansson et al, 2011; Mayer et al., 2009; Perkins et al., 2011; Shin et al., 2011; Stark 2003 \& Taylor and 
Kuo 2009). However, there has yet to be a study that isolates and directly manipulates the required style of information processing. The present study sought to parse out these differences between bottom-up and top-down processing by directly manipulating the attentional requirements across conditions.

Across ART studies (Berman et al., 2008; Berman et al., 2012; Berto, 2005; Bodin \& Hartig, 2003; Chen et al., 2011; Cimprich \& Ronis, 2003; Hartig et al, 1991; Hartig et al., 1996; Hartig, Evans, Jammer, Davis \& Garling 2003; Johansson et al., 2011; Kuo, 2001; Laumann et al, 2003; Mayer et al., 2009; Ottosson \& Grahn 2005; Perkins et al, 2011; Rich, 2008; Shin et al, 2011; Stark, 2003; Taylor et al., 2002; Taylor \& Kuo 2009; Tennessen \& Cimprich, 1995; van den Berg et al., 2003; van den Berg and van den Berg, 2011; Wu, Chang, Hsu, Lin \& Tsao, 2008), directed attention has been measured in different ways. Directed attention is linked to higher order mental functions such as working memory, when an experimental condition requires an individual to hold and replay visual and auditory stimuli or to manipulate the stimuli according to rules stored in short-term memory (Jonides, Lewis, Lustig, Berman \& Moore, 2008). Based on this knowledge, there are a number of tests that have been used to measure directed attention. A summary of these measurements can be found in Appendix I. Jonides et al. (2008) stressed the idea that the different measurements aimed at measuring directed attention may be tapping into slightly different aspects of directed attention capacity. Furthermore, a systematic review by Ohly, White, Wheeler, Bethel, Uloumunne, Nikolaou and Garsie (2016) suggested that future studies should employ multiple measures. Thus, two measures were selected to measure directed attention for the present study: 1) the DSB test and 2) the NCT. The systematic review by Ohly et al. (2016) found that the DSB test was one of the best measures of attention because of the obvious demands it places on working memory. The DSB has been used in many studies of which many have supported ART predictions (Berman et al., 2008; Berman et al., 2012; Bodin \& Hartig, 2003; Cimprich \& Ronis, 2003; Kuo, 2001; Ottosson \& Grahn, 2005; Perkins et al., 2011; Rich, 2008; Stark, 2003; Taylor \& Kuo, 2009; Taylor et al., 2002; Tennessen \& Cimprich, 1995). Further, Berman et al. (2008) suggested that the DSB test may be the best measurement tool to study the effects of natural exposure on directed attention. The NCT was chosen because it has also been used in several ART studies (Cimprich \& 
Ronis, 2003; Hartig et al., 2003; Ottosson and Grahn, 2005; Tennessen and Cimprich, 1995) that have shown some support for ART predictions. Also, the NCT is simple to implement: time efficient and portable (Hurlbut, 2011). Using different measurements may also shed light on the precise mechanisms by which nature may restore attentional processes (Jonides et al., 2008).

The aim of the present study was to directly manipulate attentional demands and assess whether a simulated Nature Condition with bottom-up processing would improve directed attention performance compared to a basic treadmill walk - the Control Condition, and a simulated nature condition with required top-down processing - the Perturbation Condition. ART predicts that bottom-up processing is conducive to restoring directed attention whereas top-down processing is not. Therefore, it is hypothesized that:

Walking in a simulated natural environment will be restorative to directed attention performance compared to walking in a basic treadmill condition and walking in a simulated natural environment requiring top-down processing.

\section{Methods}

\section{Participants}

A convenience sample of 22 participants, 13 female (59\%) and 9 male (41\%), with a mean age of 23 years, from Western University volunteered for this study. Recruitment posters (Appendix A) were posted throughout Western's campus. Students contacted the researcher through the provided email to learn more about the study, and if interested, to set up times for the three testing sessions. There was no participant compensation. The inclusion criteria required the participants to be a Western student who was able to walk on a treadmill at a comfortable speed for ten minutes and who could communicate in English. A letter of Information and Consent form (Appendix B) was presented and signed by each participant at the beginning of the first session. The present study was approved by the University Ethics Board (Appendix G). 


\section{Research Design}

A within-subject design was used. Each participant was tested under three different, randomly ordered environment conditions: the Control Condition, the Nature Condition and the Perturbation Condition. Each condition required the participant to walk for ten minutes. In the Control Condition, the participant's field of view included a large, 180degree blank white screen. In the Nature Condition, the participant's field of view included a large, 180-degree screen with the projection of an unfolding, simulated nature walk through a forest. The Perturbation Condition was identical to the Nature Condition except for two differences. First, birds flew towards the participant requiring responsive arm actions. Participants wore biomarkers on the back of their hands, projected as two orbs on the screen in front of them. The participant was required to utilize these orbs to hit/swat the oncoming birds as the participant walked through the simulated nature walk. Second, the simulated nature path was bumpy and hilly requiring the participant to make expected and unexpected adjustments to their balance while walking. The addition of the oncoming birds and the mechanical perturbations in the Perturbation Condition ensured top-down processing.

Figure 1 illustrates the within-session schematic design. The figure outlines the timeline in which the primary (directed attention) and secondary (mood) dependent variables were measured, as well as the placement of the fatigue intervention and the environmental condition exposure, within each session. 


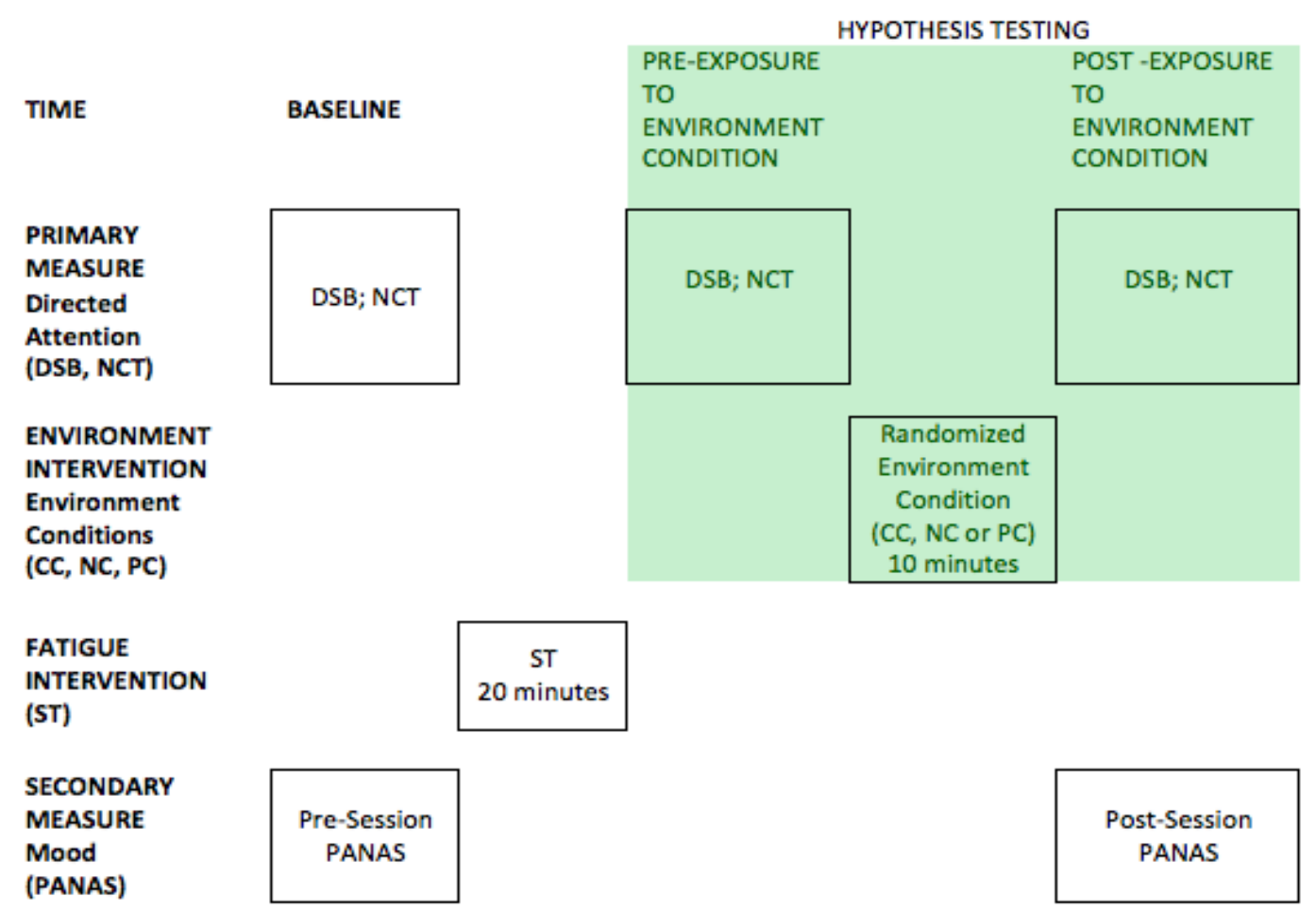

Figure 1. Within-Session Schematic

\section{Measures}

The primary dependent variable, directed attention performance, was measured using two tests: the DSB test and the NCT test. The DSB test was chosen to measure directed attention in the present study because it is commonly used in the ART literature with reliable outcomes (Ohly et al., 2016) and was proposed by Berman to be the best measurement tool to study the effects of nature on directed attention (Berman et al., 2008). The NCT test was chosen to supplement the DSB test because it has also been used in several ART studies (Cimprich \& Ronis, 2003; Hartig et al., 2003; Ottosson \& Grahn, 2005; Taylor et al., 2002; Tennessen \& Cimprich, 1995) and is an easy and efficient test to implement (Hurlbut, 2011).

The DSB test is a measure of directed attention performance, as it requires the participant to hold and replay visual or auditory stimuli and to manipulate the stimuli further. The DSB is a commonly used measurement tool because it is not affected by semantics, frequency of appearance in daily life, complexity, etc. (Karatekin, 2004). Although there 
are different variations of the DSB test, the present study adopted the DSB test used in the Berman et al. (2008) study. The participant was asked to listen to a string of three to nine digits, with each digit presented verbally for one second. When prompted, the participant was asked to orally repeat the numbers presented, backwards. The numberstring increased by one digit after every two sequences. There were a total of fourteen sequences (two for each digit list), three digits being the shortest sequence list and nine digits being the longest list. Each sequence list was randomly generated by a DSB generator with the unlikelihood of any repeated sequences in the entire study (OSDNDigitSpanTester). Each sequence was recorded as either correct or incorrect. A low number of incorrect sequences demonstrated a high directed attention performance. An example of the DSB test sheet can be found in Appendix C.

The Necker Cube (NCT) is an objective measure of attention as the ability to keep the cube in a specific orientation requires directed attention (Cimprich, 1993). The frequency at which the cube appears to switch its orientation is used to measure directed attention performance (Hurlbut, 2011). The participant was asked to observe the cube with the goal of holding the cube in a specific orientation for a total of sixty seconds (Hurlbut, 2011), tapping the desk each time the participant's orientation of the cube switched. The number of times the desk was tapped was recorded. A lower score demonstrated higher directed attention performance (Cimprich, 1990). An example of the NCT can be found in Appendix D.

The Positive And Negative Affect Schedule (PANAS) test was used to measure a secondary outcome. Affect scores were used to observe whether a change in mood could account for any changes in directed attention performance. The PANAS (PANAS; Watson, Clark \& Tellegen, 1988) is a form that lists a collection of mood-related adjectives. On a scale from 1-5 the participant was asked to indicate the extent to which they currently felt in accordance with each mood-related adjective. The scale includes both positive and negative adjectives. Although the participants filled out all twenty mood-related adjectives, only the ten positive mood-related adjectives were scored and analyzed, in accordance with the Berman et al. study (2008). A higher score represented a more positive mood. The PANAS questionnaire can be found in Appendix E. 
The Stroop task (ST) was used as an attempt to fatigue each participant's directed attention. The Stroop task requires the use of directed attention and therefore should fatigue directed attention after a prolonged time of participation. Many ART studies include a fatiguing task in the study design to ensure directed attention fatigue prior to each environment condition exposure. This helps to ensure uniformity and to detect differences in directed attention restoration (Berman et al., 2008; Hartig et al., 1991). The present study chose to use the Stroop task, as have other studies (Hartig et al., 1991; Hartig et al., 2003), to fatigue the participant's directed attention. A word was displayed in an ink colour different from the colour actually named. Two variations for the Stroop task were used successively, each variation lasting ten minutes. The first variation required the participant to name the colour of the ink instead of the written word. The second variation required the same task, except when the word was presented in red ink, the participant was asked to name the word instead of the ink colour. The number of correct responses and percentage of correct responses was automatically calculated by the Stroop task App being used, but not recorded for further analysis. (De Young, 2014). An example of the Stroop task can be found in Appendix F.

\section{Procedure}

Each participant was required to participate in all three conditions. The participants began the study at the time they were recruited, which took place over a period of approximately two months (February $1^{\text {st }} 2017-$ March $31^{\text {st }} 2017$ ). For most of the participants $(n=18)$, the sessions were spread out by exactly one week, keeping the same day of the week and same time of the day for each session. Some of the participants $(n=4)$ were not able to fit this into their schedule, thus, day of the week varied. A random testing order was assigned to each participant. Table 1 displays the number of participants who participated in each condition according to their session order.

Table 1. Condition Participation Order

\begin{tabular}{lccc}
\hline & Control Condition & Nature Condition & Perturbation Condition \\
\hline Session \#1 & 3 & 8 & 11 \\
Session \#2 & 10 & 9 & 3 \\
Session \#3 & 9 & 5 & 8 \\
\hline
\end{tabular}


Table 2 displays the protocol for each session. The first session was approximately ten minutes longer, which accounted for an additional five minutes at the beginning of the session for the participant to read over the Letter of Information and Consent (Appendix B) and an additional five minutes for the participant to practice the DSB test. There were six digit span sequences used for all participants as sequences to practice before beginning the first session to ensure the participant fully understood the task prior to beginning the study. The six sequences began with a three-digit sequence, increasing by one digit each sequence. The order in which the DSB test and the NCT was completed varied between participants, depending on the randomized order the participant was assigned - the order remained the same for each participant throughout their three sessions, only varying between participants. For the treadmill portion, the participant was given the option to walk in walking shoes or socks and was asked to make the same choice for all three sessions. For safety, the participant was strapped into a harness while walking on the treadmill for all three conditions. For the first session, the participant was asked to indicate a comfortable walking speed and this speed was recorded and used for all sessions. A photo of the treadmill setup can be found in Appendix H. After the third session, the participant was asked if they had any questions concerning the study and thanked for their participation.

Table 2. Session Testing Order and Duration for Each Segment

\begin{tabular}{ccc}
\hline Time & Description & Additive Time \\
\hline 2 minutes & Review overall protocol for the session & 2 minutes \\
2 minutes & PANAS Questionnaire Pre-Session (1) & 4 minutes \\
5 minutes & DSB Test Baseline (1) & 9 minutes \\
1.5 minutes & NCT Baseline (1) & 10.5 minutes \\
10 minutes & ST (Fatiguing Task) Variation 1 & 20.5 minutes \\
10 minutes & ST (Fatiguing Task) Variation 2 & 30.5 minutes \\
5 minutes & DSB Pre-Exposure (2) & 35.5 minutes \\
1.5 minutes & NCT Pre-Exposure (2) & 37 minutes \\
5 minutes & Adjust and situate participant on treadmill & 42 minutes \\
10 minutes & Treadmill condition exposure & 52 minutes \\
5 minutes & DSB Post-Exposure (3) & 57 minutes \\
1.5 minutes & NCT Post-Exposure (3) & 58.5 minutes \\
2 minutes & PANAS Questionnaire Post-Session (2) & 60.5 minutes \\
5 minutes & Time for questions or concerns & 65.5 minutes \\
\hline
\end{tabular}




\section{Data Analysis}

The primary dependent variable was the directed attention performance, measured with two different tests: the DSB test and the NCT. Both dependent variables were measured three times during each session: 1) Baseline: at the beginning of each session, 2) Preexposure: after the fatigue-intended Stroop task/before the exposure to the environment condition and 3) Post-exposure: after the exposure to the environment condition (See Table 1 for testing order per session). The secondary dependent variable was positive mood, measured by the PANAS Questionnaire at the beginning and end of each session.

SPSS was used to compute descriptive statistics. The DSB test, NCT and PANAS scores were analysed separately. A 3 x 3 repeated measures analysis of variance (ANOVA) with two within-subjects factors: environment condition (Control, Nature, Perturbation) and time of test (Baseline, Pre-exposure, Post-exposure) was completed for the DSB and NCT scores. Follow-up One-Way ANOVAs and t-tests were completed when necessary. A $2 \times 3$ repeated measures analysis of variance (ANOVA) with two within-subjects factors: environment condition (Control, Nature, Perturbation) and time of test (Presession, Post-session) was completed for the PANAS scores. A significance level of $\mathrm{p}<0.05$ was used for all tests.

\section{Results}

\section{Descriptive Statistics}

Table 3 displays the means and standard deviations for each test across all three environment conditions. The DSB mean scores ranged from 5.41 to 7.64. The NCT mean scores ranged from 5.55 to 6.41 . However, the standard deviations for the NCT are much larger compared to the DSB standard deviations: DSB ( $\left.\mathrm{SD}_{\text {mean }}=2.64\right)$; $\mathrm{NCT}$ $\left(\mathrm{SD}_{\text {mean }}=5.46\right)$. The PANAS mean scores ranged from 26.55 to 31.55 . 
Table 3. Descriptive Statistics: DSB, NCT, PANAS

\begin{tabular}{cccccccccc}
\hline \multirow{2}{*}{ Measure } & \multicolumn{3}{c}{ Control Condition } & \multicolumn{3}{c}{ Nature Condition } & \multicolumn{3}{c}{ Perturbation Condition } \\
& $\begin{array}{c}\text { Base- } \\
\text { line }\end{array}$ & $\begin{array}{c}\text { Pre- } \\
\text { Exposure }\end{array}$ & $\begin{array}{c}\text { Post- } \\
\text { Exposure }\end{array}$ & $\begin{array}{c}\text { Base- } \\
\text { line }\end{array}$ & $\begin{array}{c}\text { Pre- } \\
\text { Exposure }\end{array}$ & $\begin{array}{c}\text { Post- } \\
\text { Exposure }\end{array}$ & $\begin{array}{c}\text { Base- } \\
\text { line }\end{array}$ & $\begin{array}{c}\text { Pre- } \\
\text { Exposure }\end{array}$ & $\begin{array}{c}\text { Post- } \\
\text { Exposure }\end{array}$ \\
\hline \multirow{2}{*}{ DSB } & $6.73^{1}$ & 6.27 & 6.45 & 7.27 & 6.86 & 5.41 & 7.64 & 6.86 & 6.50 \\
& $(2.66)^{2}$ & $(2.62)$ & $(2.60)$ & $(2.81)$ & $(2.80)$ & $(2.22)$ & $(2.63)$ & $(2.88)$ & $(2.58)$ \\
NCT & 5.95 & 6.09 & 6.41 & 5.69 & 6.14 & 5.55 & 6.18 & 6.27 & 6.00 \\
& $(4.89)$ & $(5.71)$ & $(5.68)$ & $(5.03)$ & $(5.14)$ & $(5.78)$ & $(6.03)$ & $(5.11)$ & $(5.73)$ \\
\multirow{2}{*}{ PANAS } & 28.55 & & 26.55 & 29.86 & & 29.27 & 31.55 & & 31.41 \\
& $(7.99)$ & & $(7.91)$ & $(6.24)$ & & $(6.83)$ & $(6.74)$ & & $(8.06)$ \\
\hline
\end{tabular}

1 Mean

${ }^{2}$ Standard Deviation

Figure 2 demonstrates the mean condition outcomes for the DSB test score. The $3 \times 3$ ANOVA for the DSB scores produced a non significant environment condition main effect, $\mathrm{F}(2,42)=1.51, \mathrm{p}=0.07$ and a significant time of test main effect, $\mathrm{F}(2,42)$ $=14.45, \mathrm{p}=0.00$. Importantly, the analysis produced a significant condition $\mathrm{x}$ time of test interaction, $\mathrm{F}(4,84)=3.46, \mathrm{p}=0.01$. To control for experiment-wide Type I error rates, only the simple One-Way ANOVAs for the three exposure environment conditions at Baseline, Pre-exposure and Post-exposure were run. Only the ANOVA for the Postexposure test time was significant, $\mathrm{F}(2,42)=5.94, \mathrm{p}=0.01$. The $\mathrm{t}$-test analysis found the Nature Condition to be significantly better than the Control Condition, $\mathrm{t}(21)=2.75, \mathrm{p}=$ 0.01 and the Perturbation Condition, $\mathrm{t}(21)=3.20, \mathrm{p}=0.00$. 


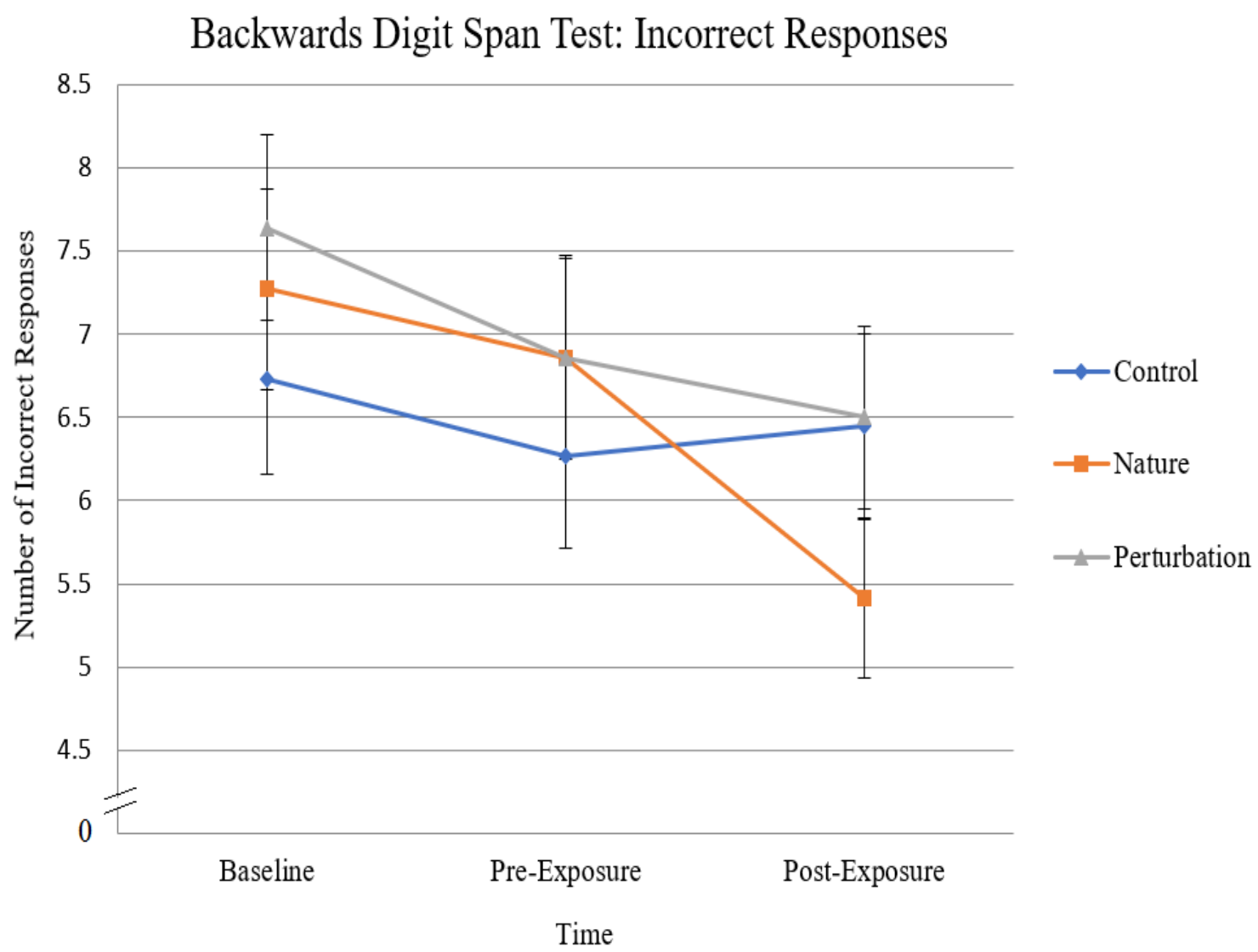

Figure 2. Performance on the Backwards Digit Span Test

Figure 3 demonstrates the mean condition outcomes for the NCT tests. The $3 \times 3$ ANOVA for the NCT scores produced a non significant environment condition main effect, $\mathrm{F}(2,42)=0.40, \mathrm{p}=0.67$, a non significant time of test main effect, $\mathrm{F}(2,42)=$ $0.24, p=0.79$. The analysis produced a non significant condition $x$ time of test interaction, $\mathrm{F}(4,84)=0.64, \mathrm{p}=0.64$. The trends for the Post-exposure scores are similar in both tests, however, the NCT findings were not significant with high standard deviations, therefore, none of the differences were reliable. 


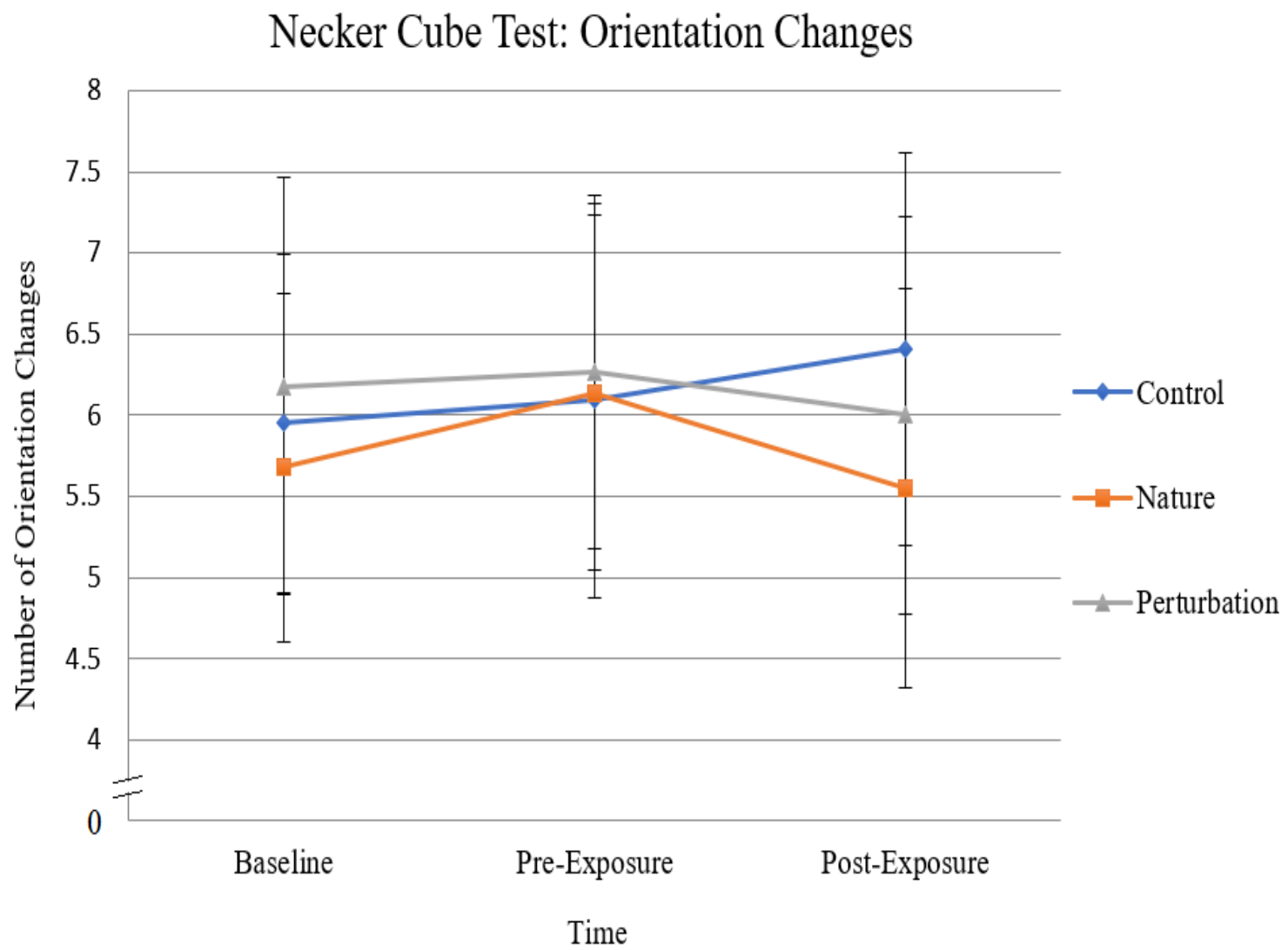

Figure 3. Performance on the Necker Cube Test

\section{Secondary Outcome Findings}

Figure 4 demonstrates the mean condition outcomes for the PANAS test including the Pre-session scores and the Post-session scores. The $3 \times 2$ ANOVA for the PANAS scores produced a significant environment condition main effect, $\mathrm{F}(2,21)=7.88, \mathrm{p}=0.01$, a non significant time of test main effect, $F(1,21)=2.16, p=0.16$. Importantly, the analysis produced a non significant condition $\mathrm{x}$ time of test interaction, $\mathrm{F}(2,42)=1.60, \mathrm{p}$ $=0.22$. 


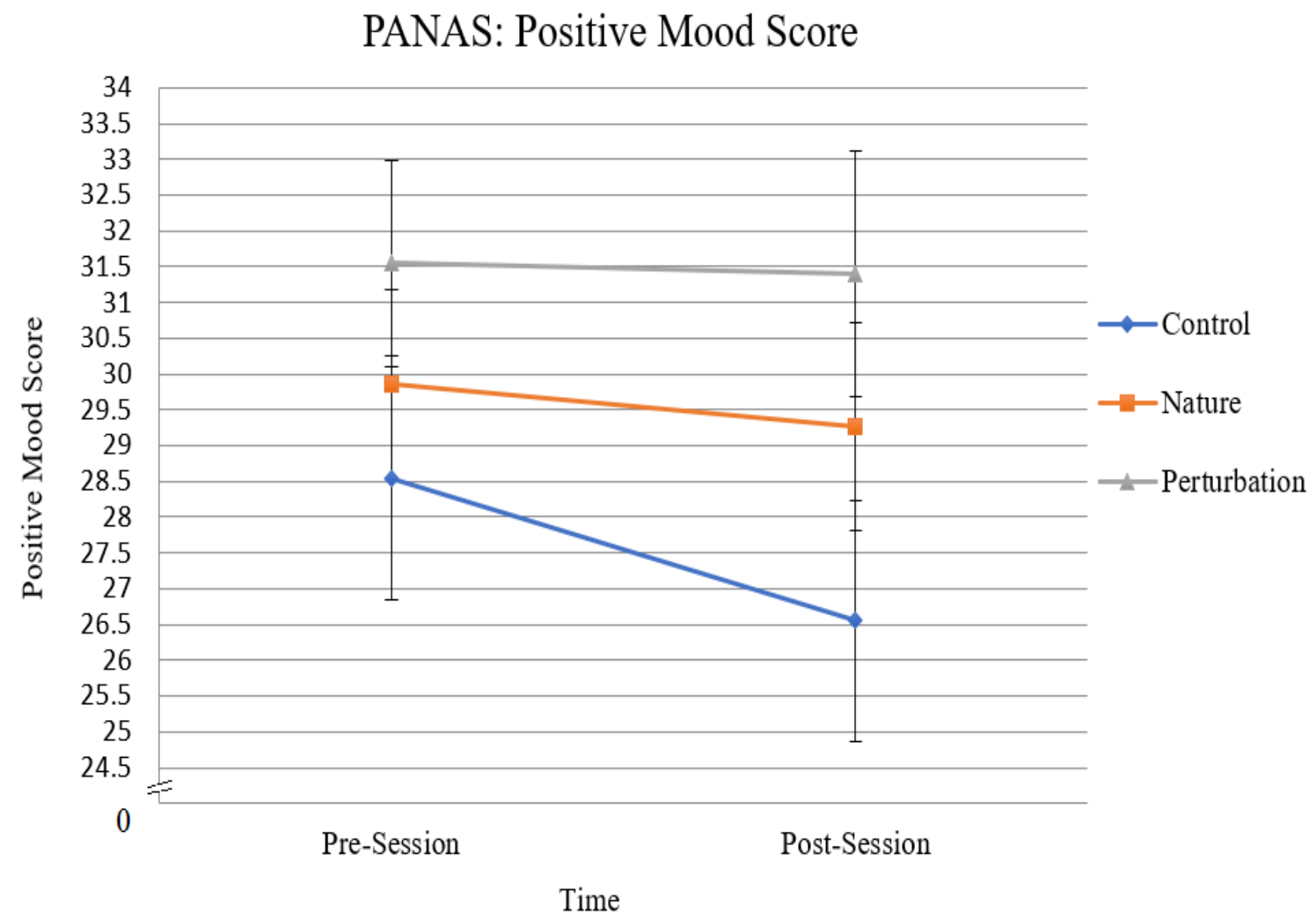

Figure 4. PANAS Positive Mood Scores

\section{Discussion}

ART predicts that an environment dominated by top-down processing will not be conducive to directed attention restoration, whereas an environment with bottom-up processing, as is experienced in nature, will be. In the present study ART predicts that the Nature Condition would be a restorative environment compared to the Control Condition. ART also suggests that the top-down processing required in the Perturbation Condition would nullify the restorative effects of nature. The results of the analyses for the DSB test supported these predictions. These findings coincide with the Berman et al. (2008) study that found a fifty-minute walk through a natural environment significantly improved DSB performance but not when the participants walked through an urban environment. Importantly, the present study provides a more direct test of ART. Although Berman et al. (2008) compared an urban environment with probable top-down processing versus a natural environment with probable bottom-up processing, Berman et al.'s (2008) study 
did not directly manipulate the attentional top-down processing variable. The present study demonstrated that when top-down processing is placed in a natural environment, the top-down processing nullified the restorative nature effect, as ART would predict. Similar to the findings by Berman et al. (2008) it is important to note that because the PANAS positive mood score outcomes were not significant, this demonstrated that the DSB results could not be explained by changes in positive mood.

The improved DSB scores after the exposure to the Nature Condition is no surprise as ART research has produced many similar findings. A component the present study adds to the ART literature is the simulated natural environment used for the intervention. While there have been several studies that examined the restorative effects of nature by viewing photos, videos or observing the outdoors through a window (Berman et al., 2008; Berto 2005; Chen et al., 2011; Hartig et al., 1996; Laumann et al., 2003; Tenessen \& Cimprich, 1995), there are no ART studies that have explored the restorative effects of physical activity engagement in a simulated natural environment. The present study incorporated a simulation of a walk through nature that was shown to restore directed attention. Furthermore, the improved directed attention following the Nature Condition exposure demonstrated that only a short, ten-minute exposure period is needed to have a restorative effect on directed attention.

It is important to consider why a simulated natural environment is restorative and how the effects of a simulated natural environment might compare to an authentic natural environment. As stated earlier, ART predicts that an environment with bottom-up processing will be conducive to directed attention restoration, a component central to the present study. Kaplan (1995) proposed that nature is generally restorative because natural environments possess four components that create a restorative effect: 1) Being Away: an environment that allows one to feel "away" from their typical environment; 2) Extent: an environment that possesses richness, creating "another world" for one to become "lost" in; 3) Fascination: the attention component, an environment that captures the individual's attention with innate interest; and 4) Compatibility: an environment that fulfills one's purpose. It seems reasonable to suggest that these components can be met through a simulation of a natural environment. Nevertheless, are simulated natural environments as 
restorative as authentic natural environments? It could be predicted that a simulated natural environment might require more directed attention to focus on the simulation and exclude distracting sceneries compared to an authentic natural environment (Kjellgren \& Buhrkall, 2010). Several studies have shown that an unauthentic depiction of nature can have restorative effects (Berman et al., 2008; Berto 2005; Chen et al., 2011; Hartig et al., 1996; Laumann et al., 2003). Although a simulated natural environment may be less restorative when compared to an authentic natural environment, ignoring the restorative effects that simulated natural environments could provide for directed attention would be ill-advised. Natural environments are not always accessible to all individuals at all times, therefore it is important to consider other ways in which individuals can experience the restorative effects of nature, such as is possible through simulations.

The use of the term "restorative" found in ART literature is noteworthy and warrants discussion. Most ART studies are focused on measuring the restorative effects of various environments, therefore, it is important that directed attention is first fatigued before restoration can be measured. Thus, many studies have implemented a fatiguing task into the study design (Berman et al., 2008; Berto, 2005; Hartig et al, 1996; Hartig et al., 2003; Laumann et al., 2003; Rich, 2008; Taylor \& Kuo, 2009; van den Berg et al., 2003). However, there have only been a handful of ART studies that: 1) included a baseline measurement; and 2) measured the actual fatiguing effect (Ohly et al., 2016). In addition, in most of the studies that did include a fatiguing task, the specific procedures were not disclosed. The fatigue intervention is a common weakness amongst ART studies and consequently the present study incorporated a baseline measurement, fatigue-intended task (Stroop task), and an instrument to measure the effects of the fatigue-intended task (DSB) to avoid this design weakness. It was assumed that directed attention performance would decline after the fatiguing task. The present study conducted several pilot tests to examine the fatiguing effects of the Stroop task on DSB scores. However, most of the participant's DSB scores in the pilot testing improved after the fatigue-intended Stroop task, across several different experimental times (ten to twenty minutes). Although a fatiguing effect was not found, the Stroop task remained in the design as it had been used as a fatiguing task in prior ART studies (Hartig et al., 1991; Hartig et al., 2003) and remained at twenty minutes because the twenty minutes was found to be all that was 
tolerable by the participants. It is important to note that although the DSB scores showed a slight improvement following the Stroop task, the NCT scores showed a non significant trend for a slight decline in directed attention performance. While a fatigue effect was not found, having a baseline test and a fatigue-intended task is still seen as a strength in the present study. The limitation for the present study was in being able to induce directed attention fatigue and/or perhaps to accurately measure it. Anecdotal comments by participants seemed to indicate they were fatigued, as many commented that they felt "tired" after completing the Stroop task.

It is important to note the significant findings for the DSB test compared to the non significant findings for the NCT test. Although the NCT findings were not significant, the changes in directed attention performance were similar for the two dependent variables (Figure 2 and 3). In the present study, the NCT test produced much higher standard deviations compared to the DSB test. The NCT relied on the participant to count the number of orientation changes, compared to the DSB where the researcher recorded the outcomes. A few participants voluntarily provided statements about the NCT concerning how they went about approaching the test. This included very different conceptual approaches to the test including one participant who viewed the cube as a house. The performance outcomes for the DSB test were much more consistent, with the performance scores ranging from 1-12, whereas the NCT performance scores ranged from $0-24$. This suggests that the NCT is a less reliable measure of directed attention compared to the DSB and that another test such as the Attention Network Task (ANT), also used in the Berman et al. (2008) study, may be a better test to pair with the DSB test (Ohly et al., 2016).

\section{Limitations}

A limitation of the present study lies in the randomization of condition order. Although random assignment is usually a strong design choice, having a small number of participants $(n=22)$ in the present study resulted in an imbalance in the order conditions experienced across participants (see Table 1). Berman et al.'s (2008) study included a counterbalance approach which may have been a more effective design choice for the 
present study and should be taken into consideration for future studies, particularly with smaller sample sizes.

A second limitation that has already been touched on in the Discussion was the inability to either produce or to measure directed attention fatigue. As stated in Ohly et al.'s (2016) systematic review, it is a weakness to be unable to measure a fatigue effect. Four suggestions are provided in an attempt to understand the failure to either produce or measure directed attention fatigue in the present study. First, the tests used to measure directed attention fatigue were not sensitive enough. In the present study, the DSB and NCT tests were used to measure the directed attention fatigue. The DSB test was sensitive enough to detect directed attention restoration in the Nature Condition, therefore, it seems less plausible that the DSB test would be incapable of detecting directed attention fatigue. Second, the fatiguing task was not powerful enough. In the present study, the Stroop task required the use of directed attention and therefore, when required to do the Stroop task for a prolonged period of time, directed attention should have been fatigued. The Stroop task was used by Hartig et al. $(1991 ; 2003)$ to produce directed attention fatigue, therefore, it is less plausible that the choice of the Stroop task is the reason for a lack of directed attention fatigue. Third, the fatiguing task duration was too short. In the present study, the participants were asked to complete the Stroop task for a total of twenty minutes. Previous studies have implemented longer fatiguing tasks. For example, Berman et al. (2008) used a thirty-five-minute fatiguing task and Hartig et al. (2003) required participants to perform the Stroop task for twenty-eight minutes, followed by a binary task for twenty minutes. However, other studies have implemented shorter fatiguing tasks, such as the study by Berto (2005), which implemented the sustained attention to response test (SART) for just under five minutes. Fourth, in the present study the participants upon arrival were already fatigued. This may be the most likely reason a fatigue effect was not detected. As stated earlier, university students are constantly using directed attention throughout a typical school day, therefore, it is likely that the participants arrived to the lab on campus either fatigued from their typical school day or at the very least, from travelling to the lab. Perhaps a strategy that could have been implemented in the present study would have been to require the participants to continue the Stroop task until there was a decline in directed attention performance, as seen in the 
DSB scores. An alternative strategy would be a hybrid of the prior suggestion combined with Hartig et al.'s (2003) strategy. Hartig et al. (2003) used the Stroop task as the fatigue task but also used the task to measure directed attention fatigue. Once fatigue is detected in the Stroop task scores, the fatigue task would end. Another suggestion would be to use naturalistic fatigue induction protocols, such as sampling participants after an exam or lecture (Hartig \& Staats, 2006; Karmanov \& Hamel, 2008).

\section{Implications for Future Research}

A consideration not included in the present study was to understand how each participant related to nature using the Perceived Restoration Scale. As Kaplan suggested, four components must be met in order for the environment to be restorative (Kaplan, 1995). This is an individualized assessment, as each person will have different perceptions about nature. Therefore, it may have been interesting to gain a perspective of what a natural environment meant to the participant and how that related to their directed attention performance results. However, this scale is difficult to use as it is suggested that the individual may respond in various ways depending on past experiences, their interpretation of the wording and the stimulus attributes (Pasini, Berto, Brondino, Hall \& Ortner, 2014). Furthermore, Kaplan and Kaplan (1989) suggested that human beings are biologically organised to respond to natural environments in a direct way, that is, by experiencing strong levels of "restorativeness". Kaplan's theory is based on the premise that the four components will generally be present in natural settings and be effective for the majority of individuals. Therefore, ART research has seldom taken an individual difference approach, however, this approach may ultimately be useful, particularly for application strategies.

A question to consider moving forward is how the restorative effects would compare between walking in an authentic natural environment compared to a walk engaged in a simulated nature walk. The study by Mayer et al. (2009) noted that walking in a natural environment produced larger improvements in directed attention compared to simply watching a nature video. There has yet to be a study that more directly compares an authentic natural environment to a simulated natural environment. Such a study 
intervention could use a within-subject design comparing two conditions: one condition requiring the participant to walk an authentic nature trail compared to the other condition requiring the participant to walk a simulated nature trail, similar to the trail walked in the authentic nature condition.

The present study pushed the minimal time boundaries needed for the Nature Condition to have a restorative effect on directed attention. It would be interesting for future research to focus on different exposure times to natural environments and measure the effectiveness or magnitude of their associated effects.

Lastly, as Ohly et al.'s (2016) systematic review stated, it would be useful to find an effective measurement tool and to use this tool across all ART studies. This means that there must be a better understanding of the mechanisms for attention restoration and the best way to measure them. This would then allow for a "gold-standard" measurement tool to be used across all ART research, making results more easily comparable and transferable. Furthermore, it would be beneficial to have a "gold-standard" fatiguing task used across all ART studies, as this seems to be a significant weakness in many ART studies.

\section{Practical Contributions}

Many public health and environmental sectors have already invested resources towards initiatives which use natural environments as a means to improve public health (Bowler, Buyung-Ali, Knight \& Pullin, 2010). It is time that universities, places for individuals to flourish and grow, provide the best environment suitable for learning. ART has been supported in many studies, suggesting that natural environments provide restorative effects for directed attention.

The present study demonstrated that only ten minutes is needed in a simulated natural environment to produce restorative effects. These findings are especially significant for university students as their break between class is typically ten minutes. Implementing natural, restorative environments throughout campus would enable students to restore directed attention between classes by simply walking from class to class. Further, 
simulated natural environments could be implemented throughout campus when nature is less accessible. In addition, professors could include short "nature" breaks (videos/photos) for students in the classroom to quickly restore directed attention. This would impact the design of lectures and furthermore, the design of university campuses, to allow for more restorative environments and practices, and therefore a better learning environment.

Although this study focuses on a university student population, this study's findings would most likely be generalizable to other groups. For example, it would be interesting to build on these findings and investigate whether they are applicable to the workforce population. A large percentage of the population spends their day inside an office, working long hours. If this study's findings are generalizable to other settings and ages, this would suggest significant changes to work environments, where optimal directed attention is necessary.

\section{Conclusion}

In the life of a university student, there is a high demand for constant use of directed attention throughout the day. By gaining a deeper understanding of the mechanisms in which nature affects cognition, these mechanisms can be implemented to create restorative environments to aid in a better overall learning experience for students. The findings of this study support ART predictions and are significant for theory and should also have many practical implications. 


\section{References}

Barton, J., \& Pretty, J. (2009). What is the Best Dose of Nature and Green Exercise for Improving Mental Health? A Multi-Study Analysis. Environmental Science \& Technology. doi:10.1021/es903183r.

Berman, M., Jonides, J. and Kaplan, S. (2008). The Cognitive Benefits of Interacting With Nature. Psychological Science, 19(12), pp.1207-1212. doi:10.1111/j.14679280.2008 .02225 .

Berman, M. G., Kross, E., Krpan, K. M., Askren, M. K., Burson, A., Deldin, P. J., Jonides, J. (2012). Interacting with nature improves cognition and affect for individuals with depression. Journal of Affective Disorders, 140(3), 300-305. doi:10.1016/j.jad.2012.03.012.

Berto, R. (2005). Exposure to restorative environments helps restore attentional capacity. Journal of Environmental Psychology, 25(3), 249-259. doi:10.1016/j.jenvp.2005.07.001.

Bodin, M., \& Hartig, T. (2003). Does the outdoor environment matter for psychological restoration gained through running? Psychology of Sport and Exercise, 4(2), 141153. doi:10.1016/s1469-0292(01)00038-3.

Bowler, D. E., Buyung-Ali, L. M., Knight, T. M., \& Pullin, A. S. (2010). A systematic review of evidence for the added benefits to health of exposure to natural environments. BMC Public Health, 10(1). doi:10.1186/1471-2458-10-456.

Buschman, T.J., \& Miller, E.K. (2007). Top-down versus bottom-up control of attention in the prefrontal and posterior parietal cortices. Science, 315, 1860-1862

Chen, C., Lai, Y.H., \& Wu J.P. (2011). Restorative affections about directed attention. recovery and reflection in different environments. Chinese Mental Health Journal 25:681-85.

Cimprich, B. (1990). Attentional fatigue and restoration in individuals with cancer.

Health and Environment Sciences. http://deepblue.lib.umich.edu/bitstream/2027.42/128498/2/9023531.pdf.

Cimprich, B. (1992). Attentional fatigue following breast cancer surgery. Research in Nursing and Health, 15, 199-207. 
Cimprich, B. (1993). Development of an intervention to restore attention in cancer patients. Cancer Nursing, 16,83-92.

Cimprich, B., \& Ronis, D.L. (2003). An environmental intervention to restore attention in women with newly diagnosed breast cancer. Cancer Nursing 26:284-92. doi:10.1097/00002820-200308000-00005.

Cornwell, H. G. (1976). Necker cube reversal: sensory or psychological satiation? Perceptual and Motor Skills, 43,2-10.

Cowan, N. (1995). Attention and memory: An integrated framework. New York: Oxford University Press.

De Young, R. (2014). Using the Stroop effect to test our capacity to direct attention: A tool for navigating urgent transitions. Retrieved from: http://www.snre.umich.edu/eplab/demos/st0/stroopdesc.html.

Fan, M., \& Jin, Y. (2013). Obesity and Self-control: Food Consumption, Physical Activity, and Weight-loss Intention, Applied Economic Perspectives and Policy, Volume 36, Issue 1, 1 March 2014, Pages 125-145.

Hare, T. A., Camerer, C.F., \& Rangel, A. (2009). Self-control in decision-making involves modulation of the vmPFC valuation system. Science 324:646-48. doi:10.1126/science.1168450.

Hartig, T., Book, A., Garvill, J., Olsson, T., \& Garling, T. (1996). Environmental influences on psychological restoration. Scandinavian Journal of Psychology 37:378-93. doi:10.1111/j.1467-9450.1996.tb00670.x.

Hartig, T., Mang, M. \& Evans, G. W. (1991). Restorative effects of natural environment experience. Environment and Behavior, 23,3-26.

Hartig, T., Evans, G. W., Jamner, L. D., Davis, D. S., \& Gärling, T. (2003). Tracking restoration in natural and urban field settings. Journal of Environmental Psychology, 23(2), 109-123. doi:10.1016/s0272-4944(02)00109-3.

Hartig, T., \& Staats, H. (2006). The need for psychological restoration as a determinant of environmental preferences. Journal of Environmental Psychology. 215-226.

Elsevier Ltd. doi:10.1016/j.jenvp.2006.07.007. 
Hurlbut, J. (2011). The Necker Cube - An Alternative Measure of Direct Attention. Department of Psychology Western Caroline University. Proceedings of the National Conference On Undergraduate Research.

Johansson, M., Hartig, T., \& Staats, H. (2011). Psychological benefits of walking: Moderation by company and outdoor environment. Applied Psychology: Health and Well-Being 3:261-80. doi:10.1111/aphw.2011.3.issue-3.

Jonides, J., Lewis, R.L., Nee, D.E., Lustig, C., Berman, M.G., \& Moore, K.S. (2008). The mind and brain of short-term memory. Annual Review of Psychology 59:193-224. doi:10.1146/annurev.psych.59.103006.093615.

Karatekin, C. (2004). A test of the integrity of the components of Baddeley's model of working memory in attention-deficit/hyperactivity disorder (ADHD). Journal of Child Psychology and Psychiatry. 45 (5).

Kaplan, S. (1995). The restorative benefits of nature: Toward an integrative framework. Journal of Environmental Psychology, 15(3), 169-182. doi:10.1016/02724944(95)90001-2.

Kaplan, S., \& Berman, M.G. (2010). Directed attention as a common resource for executive functioning and self-regulation. Perspectives on Psychological Science 5:43-57. doi:10.1177/1745691609356784.

Kaplan, R., \& Kaplan, S. (1989). The Experience of Nature. A Psychological Perspective. The University of Michigan. Cambridge University Press.

Karmanov, D., \& Hamel, R. (2008). Assessing the restorative potential of contemporary urban environment(s): Beyond the nature versus urban dichotomy. Landscape and Urban Planning, 86(2): 115-125.

Kjellgren, A., \& Buhrkall, H. (2010). A comparison of the restorative effect of a natural environment with that of a simulated natural environment, Journal of Environmental Psychology, doi:10.1016/j.jenvp.2010.01.011.

Kuo, F. E. (2001). Coping with poverty: Impacts of environment and attention in the inner city. Environment and Behavior 33:5-34. doi:10.1177/00139160121972846.

Laumann, K., Gärling, T., \& Stormark, K.M. (2003). Selective attention and heart rate responses to natural and urban environments. Journal of Environmental Psychology 23:125-34. doi:10.1016/S0272-4944(02)00110-X. 
Mayer, F., McPherson Frantz, S.C., Bruehlman-Senecal, E., \& Dolliver, K. (2009). Why is nature beneficial?: The role of connectedness to nature. Environment and Behavior 41:607-43. doi:10.1177/0013916508319745.

Ohly, H., White, M.P., Wheeler, B.W., Bethel, A., Ukoumunne, O.C., Nikolaou, V., \& Garside, R. (2016). Attention Restoration Theory: A systematic review of the attention restoration potential of exposure to natural environments. Journal of Toxicology and Environmental Health, Part B, 19:7, 305-343, doi: 10.1080/10937404.2016.1196155.

Orbach, J., Ehrlich, D., \& Heath, H. A. (1963). Reversibility of the Necker cube: I. An examination of the concept of 'satiation orientation'. Perceptual and Motor Skills, 17,439458 .

OSDN Digit Span Tester 2.1.4. (2015). A Task/Test of Working Memory for Cognitive/Neuroscience Research. Sourceforge.net/projects/digitspantester/.

Ottosson, J., \& Grahn, P. (2005). A comparison of leisure time spent in a garden with leisure time spent indoors: On measures of restoration in residents in geriatric care. Landscape Research 30:23-55. doi:10.1080/0142639042000324758.

Pasini, M., Berto, R., Brondino, M., Hall, R., \& Ortner, C. (2014). How to Measure the Restorative Quality of Environments: The PRS-11, Procedia - Social and Behavioral Sciences, Volume 159, 2014, Pages 293-297, ISSN 1877-0428, http://dx.doi.org/10.1016/j.sbspro.2014.12.375.

Perkins, S., Searight, H., \& Ratwik, S. (2011). Walking in a natural winter setting to relieve attention fatigue: A pilot study. Psychology 2:777-80. doi:10.4236/psych.2011.28119.

Rich, D. (2008). Effects of exposure to plants and nature on cognition and mood: A cognitive psychology perspective. Dissertation Abstracts International: Section B: Sciences Engineering 68:4911.

Shin, W. S., Shin, C.S., Yeoun, P.S., \& Kim, J.J. (2011). The influence of interaction with forest on cognitive function. Scandinavian Journal of Forest Research 26:595-98. doi:10.1080/02827581.2011.585996.

Stark, M. A. (2003). Restoring attention in pregnancy: The natural environment. Clinical Nursing Research 12:246-65. doi:10.1177/1054773803252995. 
Taylor, A. F., \& Kuo, F.E. (2009). Children with attention deficits concentrate better after walk in the park. Journal of Attention Disorders 12:402-09. doi:10.1177/1087054708323000.

Taylor, A. F., Kuo, F.E., \& Sullivan, W.C. (2002). Views of nature and self-discipline: Evidence from inner city children. Journal of Environmental Psychology 22:4963. doi:10.1006/jevp.2001.0241.

Tennessen, C., \& Cimprich, G. (1995). Views to nature: effects on attention. Journal of Environmental Psycholgy, 15,77-85.

van den Berg, A. E., Koole, S.L., \& Van Der Wulp, N.Y. (2003). Environment preference and restoration: (How) are they related? Journal of Environmental Psychology 23:135- 46. doi:10.1016/S0272-4944(02)00111-1.

van den Berg, A. E., \& van den Berg, C.G. (2011). A comparison of children with ADHD in a natural and built setting. Child: Care, Health Developments 37:430-39.

Vohs, K. D., Baumeister, R.F., Schmeichel, B.J., Twenge, J.M., Nelson, N.M., \& Tice, D.M. (2008). Making choices impairs subsequent self-control: A limited resource account of decision making, self-regulation, and active initiative. Journal of Personality and Social Psychology 94:883-98. doi:10.1037/0022-3514.94.5.883.

Watson, D., Clark, L.A., \& Tellegen, A. (1988). Development and Validation of Brief Measures of Positive and Negative Affect - the Panas Scales. J Pers Soc Psychol 54: 1063-1070. Journal of personality and social psychology. 54. 1063-70. 10.1037//0022-3514.54.6.1063.

Wu, S. H., Chang, C.L., Hsu, J.H., Lin, Y.J., \& Tsao, S.J. (2008). The beneficial effects of horticultural activities on patients' community skill and motivation in a public psychiatric center. Proceedings of the International Symposium on Horticultur Practices and Therapy for Human WellBeing 775:55-70. 
Appendix A: Recruitment Poster

\section{Western:}

\section{PARTICIPANTS NEEDED FOR RESEARCH}

Examining the benefits of exercising in Nature

Who: any student enrolled at Western \& must be able to participate in light physical activity

What: light physical activity + simple cognitive testing

Where: Western Campus

When: 3 different|days, 1 hour each, by appointment

For more information about this study, or to participate, CONTACT: Corey Crossan, Masters Student, Kinesiology 
Appendix B: Letter of Information and Consent

\section{Western: \\ Letter of Information and Consent}

\section{Study Title: Exploring the restorative mechanism through which physical activity in nature can restore mental concentration of college students}

Principle Study Investigator:

Alan Salmoni, Ph.D. School of Kinesiology, The University of Western Ontario Email:

\section{Co-Investigators:}

Corey Crossan, M.A. student. School of Kinesiology, The University of Western Ontario Email:

\section{Purpose of the Study:}

The purpose of the study is to determine the effects experiences with nature through physical activity may have. In particular, this study will examine the benefits of being physically active in nature using a naturesimulating treadmill.

\section{Participation Eligibility Criteria:}

- $\quad$ You are 18 years of age or older

- $\quad$ You are a student attending Western University

- $\quad$ You are in good mental and physical health

- $\quad$ You are able to communicate, read and write in English

\section{Procedures involved in this Research:}

There will be three different sessions on three different days: one including physical activity on a regular treadmill, the other two including physical activity on a treadmill that simulates being active in nature. Each session will last approximately 45 minutes each. Each session will take place in Thames Hall on Western campus.

There will also be a series of cognitive tests associated with each session to assess concentration levels before and after walking on the treadmill. The cognitive tests consist of:

1) The Necker Cube Pattern Control Test: requires the participant to observe the perspective changes in a cube.

2) The Backwards Digit-Span Test: the test consists of a series of number in which the participant will be asked to repeat the numbers in the reversed order after being presented.

3) The Stroop Test: a word will be displayed in a colour different from the colour it actually names - the participant will be asked to name the colour of the ink instead of the written word.

There will be 10 minutes of light physical activity in each session. The 10 minutes of light physical activity will consist of a comfortable to brisk walking pace decided upon by the participant.

\section{Number of People to Participate in Study:}


There will be approximately 20-30 participants recruited to participate in this study.

\section{Potential Harms, Risks or Discomforts:}

There are no foreseeable harms or risks associated with participation in the study. During the study mental fatigue will be induced but will only last for a few minutes. Physical activity will take place for 10 minutes each session, however, it will be fairly light and therefore no unusual discomfort is foreseen.

\section{Potential Benefits:}

The participant may or may not receive direct benefit from participation as these cannot be guaranteed.

\section{Confidentiality:}

Your information collected in this study will be maintained with safeguards to protect your privacy and confidentiality. Your name will be provided with a numerical code, which will be associated with your name in order to protect your privacy and confidentiality. The data, without your name, will be stored on a laptop, which is password protected. Your signed letter of information and consent form will be stored in a locked drawer in the Principle Investigator's Office. Western University Health Sciences Research Ethics Board may require access to study records for quality assurance purposes. Any information provided/collected will be retained for a minimum of 5 years after which it will be destroyed. If this study is published, you will not be identified.

\section{Voluntary Participation and Withdrawal:}

You do not waive any legal rights by signing this consent form. Your participation in this study is voluntary. You may decide not to be in this study, or to be in the study now and then change your mind later. You may leave the study at any time without affecting your academic standing. We will give you new information that is learned during the study that might affect your decision to stay in the study. If you do decide to withdraw, any data you have provided will be destroyed unless you indicate otherwise.

\section{Information about the Study Results:}

I expect to have this study completed by approximately the summer of 2017. If you would like a brief summary of the results, please let me know and I will send you the summary.

\section{Questions about the Study:}

If you have any questions or need more information about the study, please contact me at:

Corey Crossan:

If you have any concerns about your rights as a participant in the way the study is conducted, please contact: Western University Office of Research Ethics

\section{CONSENT}

- I have read the information presented in this letter about a study being conducted by Dr. Salmoni and Corey Crossan of Western University.

- I have had the opportunity to ask questions about my involvement in this study and to receive additional details requested.

- I I understand that if I agree to participate in the study, I may withdraw from the study at any time with no consequences.

- I have been given a copy of this from.

- I agree to participate in this study. 
Signature:

Date:

Name of Participant (Printed):

1. Yes, I would like to receive a summary of the study's results.

Please send them to me at this email address:

Signature of person obtaining informed consent:

Name of person obtaining informed consent (Printed):

Date: 


\section{Appendix C: Backwards Digit Span}

Done:

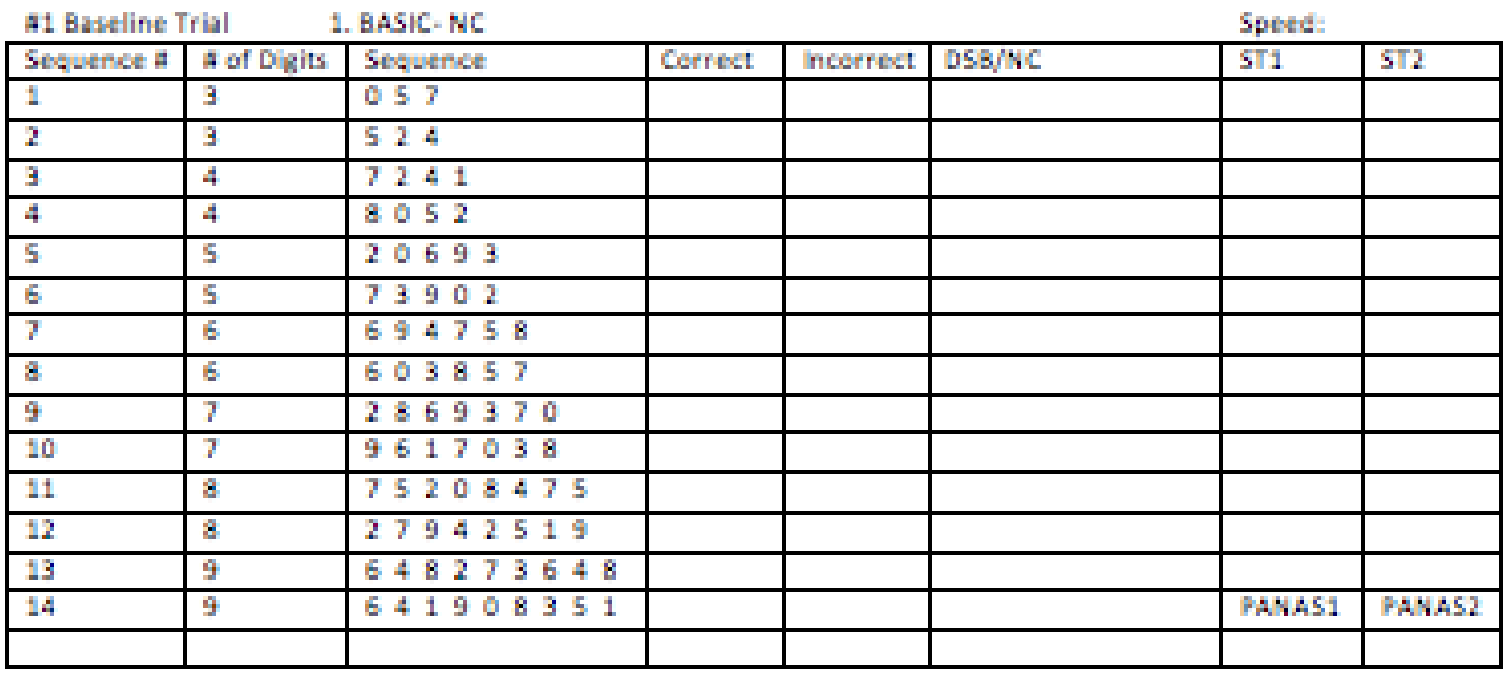

\begin{tabular}{|c|c|c|c|c|c|}
\hline Sheourted a & A sf DMits & Shourtent & Gerrwt & nowrtet. & DSS/AC \\
\hline 1 & 3 & 657 & & & \\
\hline 2 & 3 & 605 & & & \\
\hline 9 & 4 & 2746 & & & \\
\hline 4 & 4 & 5307 & & & \\
\hline 5 & 5 & 35825 & & & \\
\hline E & 5 & 82503 & & & \\
\hline 7 & E & 971820 & & & \\
\hline $\mathrm{g}$ & E & 183926 & & & \\
\hline 9 & 7 & 1569573 & & & \\
\hline 10 & 7 & 2917586 & & & \\
\hline 11 & $d$ & 75945195 & & & \\
\hline 12 & $\mathrm{~s}$ & 97358427 & & & \\
\hline 13 & 5 & 956297451 & & & \\
\hline 14 & 5 & 856972041 & & & \\
\hline & & & & & \\
\hline
\end{tabular}

\begin{tabular}{|c|c|c|c|c|c|}
\hline Shevented a & is of buits & So-difut & Curfwet & frout f het & DSBNA \\
\hline 1 & 3 & 817 & & & \\
\hline 2 & 3 & 057 & & & \\
\hline 9 & 4 & 4296 & & & \\
\hline 4 & 4 & 9668 & & & \\
\hline 5 & 5 & 25749 & & & \\
\hline$E$ & 5 & $5 \div 069$ & & & \\
\hline 7 & E & 140572 & & & \\
\hline 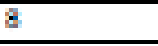 & 8 & 451305 & & & \\
\hline 9 & 7 & 5941502 & & & \\
\hline 10 & 7 & 6849375 & & & \\
\hline 11 & 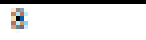 & 49825715 & & & \\
\hline 12 & 8 & 57062845 & & & \\
\hline 13 & 9 & 359418026 & & & \\
\hline 14 & 9 & 491507249 & & & \\
\hline & & & & & \\
\hline
\end{tabular}


Appendix D: Necker Cube

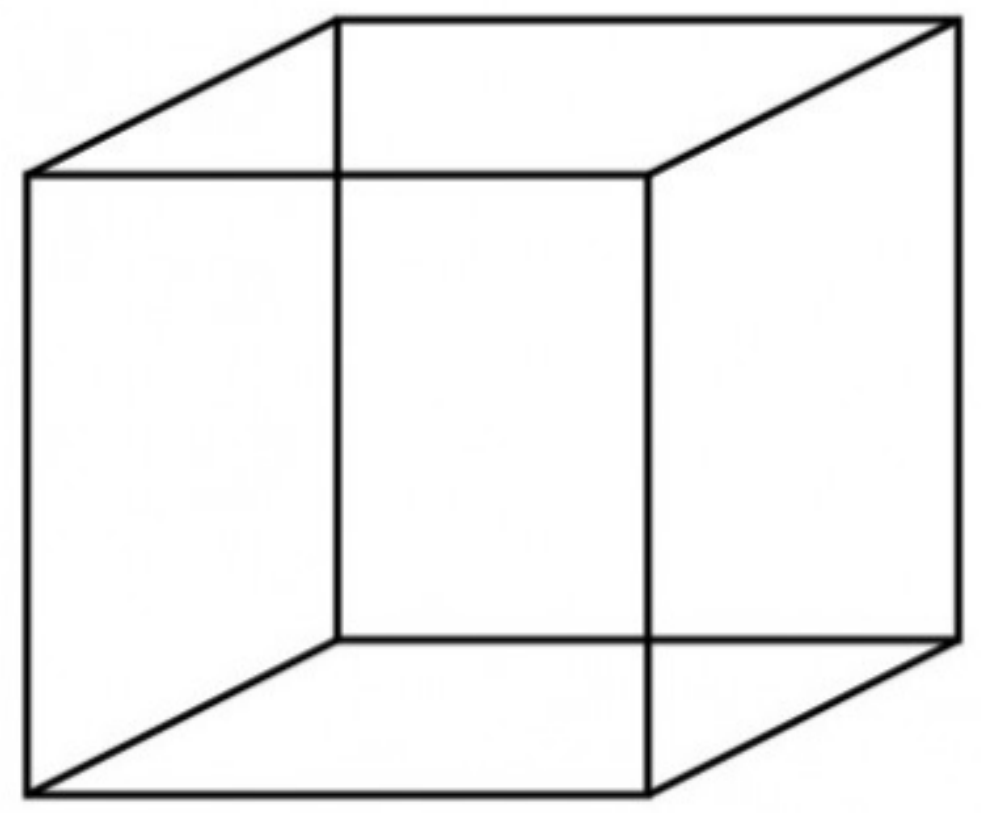

Example of the Different Orientations:
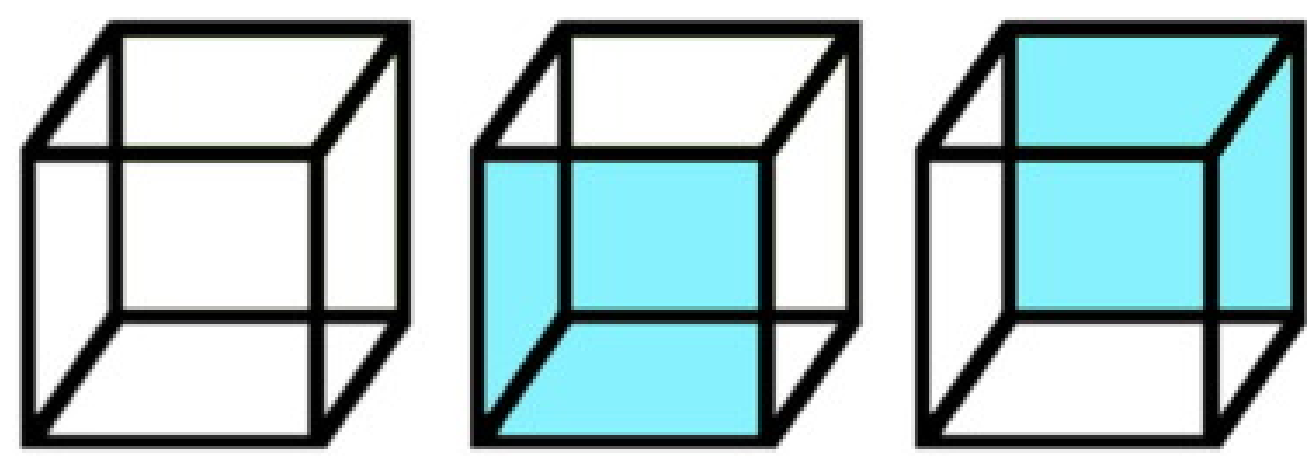
Appendix E: PANAS Questionnaire

Worksheet 3.1 The Positive and Negative Affect Schedule (PANAS; Watson et al., 1988)

PANAS Questionnaire

This scale consists of a number of words that describe different feelings and emotions. Read each item and then list the number from the scale below next to each word. Indicate to what extent you feel this way right now, that is, at the present moment OR indicate the extent you have felt this way over the past week (circle the instructions you followed when taking this measure)

Very Slightly or Not at All (1) A Little (2) Moderately (3) Quite a Bit (4) Extremely (5)

\begin{tabular}{l} 
1. Interested \\
2. Distressed \\
3. Excited \\
4. Upset \\
5. Strong \\
6. Guilty \\
7. Scared \\
8. Hostile \\
9. Enthusiastic \\
\hline 10. Proud
\end{tabular}
11. Irritable 12. Alert 13. Ashamed 14. Inspired 15. Nervous 16. Determined 17. Attentive 18. Jittery 19. Active 20. Afraid

Scoring Instructions:

Positive Affect Score: Add the scores on items 1, 3, 5, 9, 10, 12, 14, 16, 17, and 19. Scores can range from $10-50$, with higher scores representing higher levels of positive affect. Mean Scores: Momentary 29.7 ( SD 7.9); Weekly 33.3 ( SD 7.2)

Negative Affect Score: Add the scores on items 2, 4, 6, 7, 8, 11, 13, 15, 18, and 20. Scores can range from 10 - 50, with lower scores representing lower levels of negative affect. Mean Score: Momentary 14.8 ( SD 5.4); Weekly 17.4 ( SD 6.2)

Copyright 1988 by the American Psychological Association. Reproduced with permission.

Watson, D., Clark, L. A., \& Tellegan, A. (1988). Development and validation of brief measures of positive and negative affect: The PANAS scales. Journal of Personality and Social Psychology, 54(6), 1063-1070. 
Appendix F: Stroop Task

Variation 1:

$\begin{array}{ll}\text { Red } & \rightarrow \text { Yellow } \\ \text { Blue } & \rightarrow \text { Red* } \\ \text { Green } & \rightarrow \text { Red* } \\ \text { Red } & \rightarrow \text { Blue } \\ \text { Yellow } & \rightarrow \text { Green } \\ \text { Blue } & \rightarrow \text { Blue } \\ \text { Blue } & \rightarrow \text { Red* } \\ \text { Green } & \rightarrow \text { Green } \\ \text { Yellow } & \rightarrow \text { Yellow } \\ \text { Red } & \rightarrow \text { Red* }\end{array}$

Variation 2:

$\begin{array}{ll}\text { Red } & \rightarrow \text { Yellow } \\ \text { Blue } & \rightarrow \text { Blue* } \\ \text { Green } & \rightarrow \text { Green* } \\ \text { Red } & \rightarrow \text { Blue } \\ \text { Yellow } & \rightarrow \text { Green } \\ \text { Blue } & \rightarrow \text { Blue } \\ \text { Blue } & \rightarrow \text { Blue* } \\ \text { Green } & \rightarrow \text { Green } \\ \text { Yellow } & \rightarrow \text { Yellow } \\ \text { Red } & \rightarrow \text { Red* }\end{array}$

*Demonstrates the different answers because of the different variation 


\section{Appendix G: Approval by Ethics Board}

\section{Western}

Research Ethics Research

\section{Westem University Health Science Research E.thics Boari HSREB Delegated Initial Approval Notice}

Priexifal lewexlemar: Dr. Alas Salneed

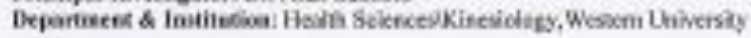

flesier Type: Delevent

IEster.B be Nenter: Itowis

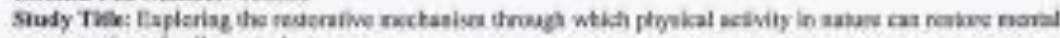
omachirsicn of collogo nuders

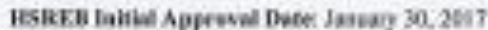
HEREEB Esping Duw: Jareacy 35, 2018

Decumsents Aprand andiar Beseinod far lafernatien:

\begin{tabular}{|c|c|c|}
\hline Dosutien Name & Comments & Version Dute \\
\hline Other & PANAS Assessment Form - Received 10/21/2016 & \\
\hline Other & The Necker Cobe - 2011 Received 10/21/2016 & \\
\hline Westem Chiversity Protood & & 20101208 \\
\hline Lether of lefoemation \& Concent & & $2016 / 12 N 8$ \\
\hline Recruitment Items & Poster & $2016 / 12 / 08$ \\
\hline
\end{tabular}

The Westem University Health Science Rescarch Ethics Board (HSREg) has reviewed and approved the above numed sudy, as of the HSREB leitial Approval Dale nolad sbove.

HSREB apgroval for this study ratains valis until the HSRFB Expiry Date soted above, conditional to timoly subenission and noceptanoe of HSREB Continaing Ethics Review.

The Westem University HSREB operales in cumplianse with the Tri-Council Policy Statement Ehical Condact for Restarch lnvolving Humans (TCPS2), the Intemacional Conserence on Harmonizatioes of Technócal Respuirements for Registration of Fhammaceuticals for Human Use Guideline for Gocd CTeieal Practice Practices (ICH E6 RIX, the Onkario Penonal Health loforeation Protection Act (PHIPA, 2004), Part 4 of the Natural Health Product Regulations, Health Canada Medical Deviee Rezulations and Part C, Division 5, of the Food and Drug Rezularioes of Health Canada.

Menbers of the HSRFB who are named as Investigators in research studies do not particlpate in Siscossians related to, nor vote on such stidies when they are presented to the RF8.

The HSREB is regislered with the U.S. Depertment of Health \& Human Services vander the IRB registration number IRB 0050094a.

Ethios Offeer, on behalf of Dr. Jeope Gilbert HSREB Chair

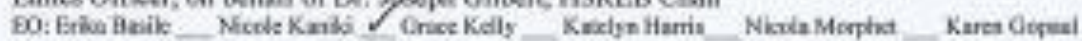


Appendix H: Treadmill Setup

This participant is completing the Perturbation Condition. The one orb is slightly noticeable on the screen in addition to the bird flying towards the participant.

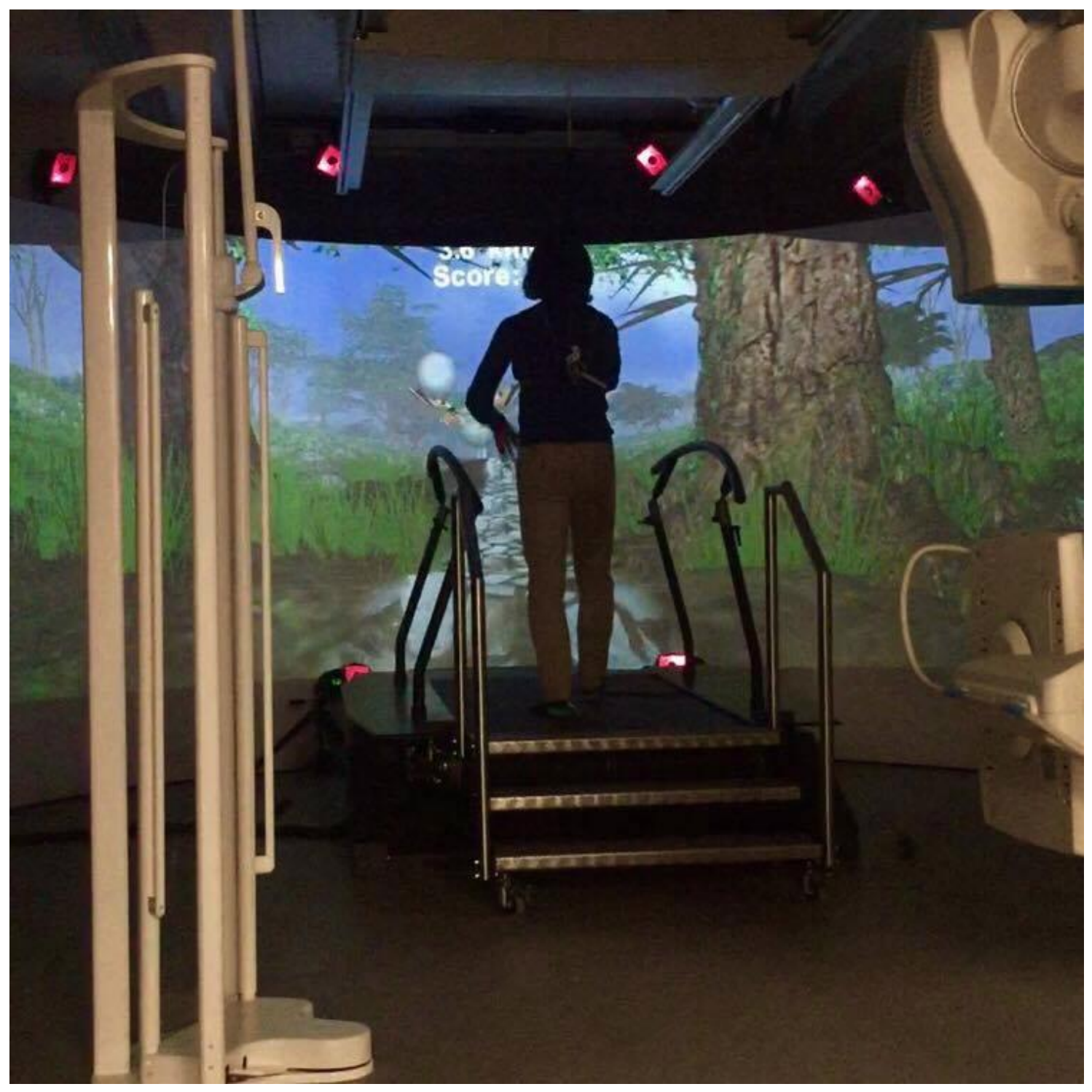




\section{Appendix I: ART Measurements}

\begin{tabular}{|c|c|c|c|}
\hline Test & Description & Studies & \# Studies \\
\hline DSB & $\begin{array}{l}\text { Repeat a series of numbers in } \\
\text { reverse order }\end{array}$ & $\begin{array}{l}\text { Cimprich and Ronis 2003, Perkins, Searight and } \\
\text { Ratwik 2011, Stark 2003, Rich 2008, Berman 2008, } \\
\text { Berman 2012, Bodin 2003, Taylor 2009, Ottosson } \\
\text { and Grahn 2005, Kuo 2001, Taylor 2002, Tennessen } \\
1995\end{array}$ & 12 \\
\hline DSF & Repeat a series of numbers & $\begin{array}{l}\text { Cimprich and Ronis 2003, Perkins, Searight and } \\
\text { Ratwik 2011, Stark 2003, Ottosson 2005, Tennessen } \\
1995\end{array}$ & 5 \\
\hline $\begin{array}{l}\text { Proof- } \\
\text { reading }\end{array}$ & Find simple grammatical errors & Hartig et al 1991 & 1 \\
\hline SMT & $\begin{array}{l}\text { Memorizes } 5 \text { target letters and } \\
\text { searches for the target letters }\end{array}$ & Mayer 2009, Hartig et al. 1996; 2003 & 3 \\
\hline SART & $\begin{array}{l}\text { React to a presentation of digits } \\
\text { from } 1-9 \text { on a screen (one digit } \\
\text { is the target) }\end{array}$ & Berto 2005 & 1 \\
\hline SDMT & $\begin{array}{l}\text { Asked to memorize } 9 \text { pairs of } \\
\text { symbols and digits }\end{array}$ & $\begin{array}{l}\text { Bodin and Hartig 2003, Tennessen and Cimprich } \\
\text { 2995, Ottosson and Grahn } 2005\end{array}$ & 3 \\
\hline SST & $\begin{array}{l}\text { Asked to fill out blanks from } 9 \\
\text { symbols and digits asked to } \\
\text { memorize }\end{array}$ & Johansson, Hartig and Staats 2011 & 1 \\
\hline TMTA & $\begin{array}{l}\text { Connect } 25 \text { numeric targets in } \\
\text { the correct ascending order }\end{array}$ & Cimprich and Ronis 2003, Stark 2003 & 2 \\
\hline ТМТВ & $\begin{array}{l}\text { Connect } 25 \text { letter targets in the } \\
\text { correct ascending order }\end{array}$ & $\begin{array}{l}\text { Cimprich and Ronis 2003, Shin et al 2011, Stark } \\
2003\end{array}$ & 3 \\
\hline NCT & $\begin{array}{l}\text { The perception of a cube is } \\
\text { asked to be held in the same } \\
\text { perception as long as possible }\end{array}$ & $\begin{array}{l}\text { Cimprich and Ronis 2003, Hartig et al 2003, } \\
\text { Ottosson and Grahn 2005, Tennessen and Cimprich } \\
1995\end{array}$ & 4 \\
\hline
\end{tabular}

(Ohly et al., 2016)

The most frequent measurement tool used to test DA performance in ART literature is the backwards digit span (DSB) test, used in 12 studies (Cimprich \& Ronis ,2003; Perkins, Searight \& Ratwik, 2011; Stark 2003, Rich 2008, Berman et al., 2008; Berman et al., 2012; Bodin, 2003; Taylor, 2009; Ottosson \& Grahn, 2005; Kuo, 2001; Taylor, 2009;

Tennessen, 1995). A slight variation is the forward digit span (DSF) test with a total of 5 studies used in ART literature (Cimprich \& Ronis, 2003; Perkins, Searight \& Ratwik, 2011; Stark, 2003; Ottosson, 2005; Tennessen, 1995). The proofreading task was used in one study (Hartig et al., 1991), the search and memory task (SMT) was used in three studies (Mayer et al., 2009; Hartig et al., 1996; Hartig et al., 2003), the sustained attention to response test (SART) was used in one study (Berto, 2005), the symbol digit modalities test (SDMT) was used in three studies (Bodin \& Hartig, 2003; Tennessen \& Cimprich, 1995; Ottosson \& Grahn, 2005), the symbol substitution test (SST) was used in one sutdy (Johansson, Hartig \& Staats, 2011), the trail making test A (TMTA) was used in two studies (Cimprich \& Ronis 2003; Stark, 2003), the trail making test B (TMTB) was used in three studies (Cimprich \& Ronis, 2003; Shin et al., 2011; Stark, 2003) and lastly, the necker cube test (NCT) was used in four studies (Cimprich \& Ronis 2003; Hartig et al., 2003; Ottosson \& Grahn 2005; Tennessen \& Cimprich, 1995). 


\section{Appendix J: Characteristics of included ART Studies}

\begin{tabular}{|c|c|c|c|c|c|}
\hline $\begin{array}{l}\text { Author, } \\
\text { Year }\end{array}$ & $\begin{array}{l}\text { Study } \\
\text { Design }\end{array}$ & $\mathrm{n}$ & $\begin{array}{l}\text { Sample Characteristics: } \\
\text { Gender, } \\
\text { Mean Age, Population, } \\
\text { Ethnicity }\end{array}$ & $\begin{array}{l}\text { Intervention Characteristics: } \\
\text { Activity, Setting, Duration of } \\
\text { Exposure }\end{array}$ & $\begin{array}{l}\text { Attention } \\
\text { Measures }\end{array}$ \\
\hline $\begin{array}{l}\text { Cimprich, } \\
2003\end{array}$ & RCT & 185 & $\begin{array}{l}100 \% \text { Female } \\
\text { Breast Cancer Patients } \\
86 \% \text { White }\end{array}$ & $\begin{array}{l}\text { Home-based } \\
\text { Control group logged relaxation } \\
120 \mathrm{~min} / \text { week } \\
\text { Pre to Post Surgery approx. } 36 \text { days }\end{array}$ & $\begin{array}{l}\text { DSB, DSF } \\
\text { NCT } \\
\text { TMTA, TMTB }\end{array}$ \\
\hline $\begin{array}{l}\text { Hartig, } \\
2003\end{array}$ & $\mathrm{RCT}$ & 112 & $\begin{array}{l}50 \% \text { Male } \\
20.8 \text { years } \\
\text { Students }\end{array}$ & $\begin{array}{l}\text { Sitting, natural view; then walking, } \\
\text { natural (nature reserve) } \\
\text { Sitting, no view; then walking, } \\
\text { urban } \\
\text { (city streets) } \\
1 \text { hour (10min passive; 50min } \\
\text { active) }\end{array}$ & $\begin{array}{l}\text { NCT } \\
\text { SMT }\end{array}$ \\
\hline $\begin{array}{l}\text { Hartig, } \\
1991 \text { (2) }\end{array}$ & RCT & 102 & $\begin{array}{l}50 \% \text { Male } \\
20 \text { years } \\
\text { Students }\end{array}$ & $\begin{array}{l}\text { Walking, natural (regional park) } \\
\text { Walking, urban (city centre) } \\
\text { Reading magazines (comfortable } \\
\text { lab) } \\
\text { 40min }\end{array}$ & Proofreading Task \\
\hline $\begin{array}{l}\text { Mayer, } \\
2009\end{array}$ & RCT & 76 & $\begin{array}{l}29 \% \text { Male } \\
\text { Students }\end{array}$ & $\begin{array}{l}\text { Walking, natural (woods/creek) } \\
\text { Walking, urban (downtown) } \\
\text { 10min }\end{array}$ & $\begin{array}{l}\text { MLST } \\
\text { SMT }\end{array}$ \\
\hline $\begin{array}{l}\text { Mayer, } \\
2009\end{array}$ & $\mathrm{RCT}$ & 92 & $\begin{array}{l}30 \% \text { Male } \\
\text { Students }\end{array}$ & $\begin{array}{l}\text { Walking, natural (woods) } \\
\text { Watching video, natural (woods) } \\
\text { Watching video, urban (busy } \\
\text { streets) } \\
\text { 10min }\end{array}$ & $\begin{array}{l}\text { MLST } \\
\text { SMT }\end{array}$ \\
\hline $\begin{array}{l}\text { Perkins, } \\
2011\end{array}$ & RCT & 26 & $\begin{array}{l}27 \% \text { Male } \\
19-24 \text { years } \\
\text { Students }\end{array}$ & $\begin{array}{l}\text { Walking, natural (woods) } \\
\text { Walking, urban } \\
\text { (residential/business) } \\
\text { Walking, urban (parking lot) } \\
\text { 20min }\end{array}$ & $\begin{array}{l}\text { DSB, DSF } \\
\text { Logical Memory }\end{array}$ \\
\hline $\begin{array}{l}\text { Stark, } \\
2003\end{array}$ & $\begin{array}{l}\text { Cluster } \\
\text { RCT }\end{array}$ & 57 & $\begin{array}{l}100 \% \text { Female } \\
29.1 \text { years } \\
\text { Pregnant Women in Third } \\
\text { Trimester } \\
94.7 \% \text { White }\end{array}$ & $\begin{array}{l}\text { Outdoor "restorative" activities" } \\
\text { Discomfort of Pregnancy Session } \\
\text { 120min/week (outdoor activities) } \\
\text { Baseline-Followup 13-64 days }\end{array}$ & $\begin{array}{l}\text { Category Matching } \\
\text { DSF, DSB } \\
\text { Error Scale } \\
\text { TMTA, TMTB }\end{array}$ \\
\hline $\begin{array}{l}\text { Berto, } \\
2005 \text { (1) }\end{array}$ & $\mathrm{RCT}$ & 32 & $\begin{array}{l}50 \% \text { Male } \\
23 \text { years } \\
\text { Students }\end{array}$ & $\begin{array}{l}\text { Viewing images, natural } \\
\text { Viewing images, urban } \\
25 \text { images x } 15 \mathrm{sec} \text { each }\end{array}$ & SART \\
\hline $\begin{array}{l}\text { Berto, } \\
2005 \text { (3) }\end{array}$ & RCT & 32 & $\begin{array}{l}50 \% \text { Male } \\
22 \text { years } \\
\text { Students }\end{array}$ & $\begin{array}{l}\text { Viewing images, natural } \\
\text { Viewing images, urban } \\
25 \text { images } x \text { duration of their choice }\end{array}$ & SART \\
\hline $\begin{array}{l}\text { Chen, } \\
2011\end{array}$ & $\mathrm{RCT}$ & 48 & $\begin{array}{l}42 \% \text { Male } \\
\text { Students }\end{array}$ & $\begin{array}{l}\text { Viewing images, natural } \\
\text { Viewing images, city } \\
\text { Viewing images, urban nightscape } \\
\text { Viewing images, sports } \\
10 \text { images x } 15 \mathrm{sec} \text { each }\end{array}$ & $\begin{array}{l}\text { Colored Number } \\
\text { Pictures }\end{array}$ \\
\hline $\begin{array}{l}\text { Hartig, } \\
1996\end{array}$ & $\mathrm{RCT}$ & 102 & $\begin{array}{l}38 \% \text { Male } \\
21.4 \text { years } \\
\text { Students }\end{array}$ & $\begin{array}{l}\text { Watching simulated walk, natural } \\
\text { (trees) } \\
\text { Watching simulated walk, urban } \\
\text { (city) } \\
\text { No simulated walk (control) } \\
80 \text { slides x } 10 \text { sec each (13.5min) }\end{array}$ & SMT \\
\hline
\end{tabular}




\begin{tabular}{|c|c|c|c|c|c|}
\hline $\begin{array}{l}\text { Author, } \\
\text { Year }\end{array}$ & $\begin{array}{l}\text { Study } \\
\text { Design }\end{array}$ & $\mathrm{n}$ & $\begin{array}{l}\text { Sample Characteristics: } \\
\text { Gender, } \\
\text { Mean Age, Population, } \\
\text { Ethnicity }\end{array}$ & $\begin{array}{l}\text { Intervention Characteristics: } \\
\text { Activity, Setting, Duration of } \\
\text { Exposure }\end{array}$ & $\begin{array}{l}\text { Attention } \\
\text { Measures }\end{array}$ \\
\hline $\begin{array}{l}\text { Hartig, } \\
1996(2)\end{array}$ & RCT & 18 & $\begin{array}{l}50 \% \text { Male } \\
27.4 \text { years } \\
\text { Students }\end{array}$ & $\begin{array}{l}\text { Watching simulated walk, natural } \\
\text { (trees) } \\
\text { Watching simulated walk, urban } \\
\text { (city) } \\
80 \text { slides manually (12min) }\end{array}$ & SMT \\
\hline $\begin{array}{l}\text { Laumann, } \\
2003\end{array}$ & RCT & 28 & $\begin{array}{l}100 \% \text { Female } \\
18-24 \text { years } \\
\text { Students }\end{array}$ & $\begin{array}{l}\text { Watching video, natural (island } \\
\text { water) } \\
\text { Watching video, urban (city streets) } \\
80 \text { scenes x } 15 \mathrm{sec} \text { each }\end{array}$ & $\begin{array}{l}\text { Posner's Attention } \\
\text { Orientating Task }\end{array}$ \\
\hline $\begin{array}{l}\text { Rich, } \\
2008\end{array}$ & $\mathrm{RCT}$ & 145 & $\begin{array}{l}17 \% \text { Male } \\
\text { Students }\end{array}$ & $\begin{array}{l}\text { Looking at view, natural (forest) } \\
\text { Looking at view, urban (buildings) } \\
\text { No view } \\
1 \mathrm{~min}\end{array}$ & $\begin{array}{l}\text { Vigilence Task } \\
\text { Sroop Task }\end{array}$ \\
\hline $\begin{array}{l}\text { Rich, } \\
2008 \text { (2) }\end{array}$ & RCT & 36 & $\begin{array}{l}42 \% \text { Male } \\
18-21 \text { years } \\
\text { Students }\end{array}$ & $\begin{array}{l}\text { Reading magazines, room with } \\
\text { plants } \\
\text { Reading magazines, room with } \\
\text { other } \\
\text { 10min }\end{array}$ & DSB \\
\hline $\begin{array}{l}\text { van den } \\
\text { Berg, } \\
2003\end{array}$ & RCT & 114 & $\begin{array}{l}32 \% \text { Male } \\
21.9 \text { years } \\
\text { Students }\end{array}$ & $\begin{array}{l}\text { Watching simulated walk, natural } \\
\text { (forest with or without water) } \\
\text { Watching simulated walk, urban } \\
\text { (city with or without water) } \\
7 \text { min }\end{array}$ & $\begin{array}{l}\text { D2 Mental } \\
\text { Concentration Test }\end{array}$ \\
\hline $\begin{array}{l}\text { Berman, } \\
2008\end{array}$ & $\begin{array}{l}\text { Random } \\
\text { ized } \\
\text { Crossov } \\
\text { er Trial }\end{array}$ & 38 & $\begin{array}{l}39 \% \text { Male } \\
22.6 \text { years } \\
\text { Students }\end{array}$ & $\begin{array}{l}\text { Walking, natural (park) } \\
\text { Walking, urban (downtown) } \\
\text { 50-55min Two walks, } 1 \text { week apart }\end{array}$ & DSB \\
\hline $\begin{array}{l}\text { Berman, } \\
2008(2)\end{array}$ & $\begin{array}{l}\text { Random } \\
\text { ized } \\
\text { Crossov } \\
\text { er Trial }\end{array}$ & 12 & $\begin{array}{l}33 \% \text { Male } \\
24.3 \text { years } \\
\text { Students }\end{array}$ & $\begin{array}{l}\text { Viewing images, natural (Nova } \\
\text { Scotia) } \\
\text { Viewing images, urban (downtown) } \\
50 \text { images in } 10 \text { min } \\
\text { Two sessions, } 1 \text { week apart }\end{array}$ & $\begin{array}{l}\text { ANT } \\
\text { DSB }\end{array}$ \\
\hline $\begin{array}{l}\text { Berman, } \\
2012\end{array}$ & $\begin{array}{l}\text { Random } \\
\text { ized } \\
\text { Crossov } \\
\text { er Trial }\end{array}$ & 20 & $\begin{array}{l}40 \% \text { Male } \\
26 \text { years } \\
\text { Adults Diagnosed with MDD }\end{array}$ & $\begin{array}{l}\text { Walking, natural (park) } \\
\text { Walking, urban (downtown) } \\
\text { 50-55min Two walks, } 1 \text { week apart }\end{array}$ & DSB \\
\hline $\begin{array}{l}\text { Bodin, } \\
2003\end{array}$ & $\begin{array}{l}\text { Random } \\
\text { ized } \\
\text { Crossov } \\
\text { er Trial }\end{array}$ & 12 & $\begin{array}{l}50 \% \text { Male } \\
39.7 \text { years (males) } 37.0 \text { years } \\
\text { (females) } \\
\text { Runners }\end{array}$ & $\begin{array}{l}\text { Running, natural (park) } \\
\text { Running, urban (city streets) } \\
\text { 60min Two runs, } 1 \text { week apart }\end{array}$ & $\begin{array}{l}\text { Combined DSB \& } \\
\text { DSF } \\
\text { SDMT }\end{array}$ \\
\hline $\begin{array}{l}\text { Johansson, } \\
2011\end{array}$ & $\begin{array}{l}\text { Random } \\
\text { ized } \\
\text { Crossov } \\
\text { er Trial }\end{array}$ & 20 & $\begin{array}{l}50 \% \text { Male } \\
24.2 \text { years (males) } 22.4 \text { years } \\
\text { (females) } \\
\text { Students }\end{array}$ & $\begin{array}{l}\text { Walking, natural (park) } \\
\text { Walking, urban (streets) } \\
\text { 40min Four walks, } 1 \text { week apart } \\
\text { Both conditions with friend and } \\
\text { alone }\end{array}$ & SST \\
\hline $\begin{array}{l}\text { Shin, } \\
2011\end{array}$ & $\begin{array}{l}\text { Random } \\
\text { ized } \\
\text { Crossov } \\
\text { er Trial }\end{array}$ & 60 & $\begin{array}{l}58 \% \text { Male } \\
23.3 \text { years } \\
\text { Students }\end{array}$ & $\begin{array}{l}\text { Walking, natural (park) } \\
\text { Walking, urban (city streets) } \\
\text { 50-55min Two walks, } 1 \text { week apart }\end{array}$ & ТМТВ \\
\hline $\begin{array}{l}\text { Taylor, } \\
2009\end{array}$ & $\begin{array}{l}\text { Random } \\
\text { ized } \\
\text { Crossov } \\
\text { er Trial }\end{array}$ & 25 & $\begin{array}{l}88 \% \text { Male } \\
9.2 \text { years } \\
\text { Children Diagnosed with } \\
\text { ADHD }\end{array}$ & $\begin{array}{l}\text { Walking, natural (urban park) } \\
\text { Walking, urban (downtown) } \\
\text { Walking, urban (neighbourhood) } \\
\text { 20min Three walks, } 1 \text { week apart }\end{array}$ & $\begin{array}{l}\text { DSB } \\
\text { Stroop Task } \\
\text { SDMT } \\
\text { Vigilance Task }\end{array}$ \\
\hline
\end{tabular}




\begin{tabular}{|c|c|c|c|c|c|}
\hline $\begin{array}{l}\text { Author, } \\
\text { Year }\end{array}$ & $\begin{array}{l}\text { Study } \\
\text { Design }\end{array}$ & $\mathrm{n}$ & $\begin{array}{l}\text { Sample Characteristics: } \\
\text { Gender, } \\
\text { Mean Age, Population, } \\
\text { Ethnicity }\end{array}$ & $\begin{array}{l}\text { Intervention Characteristics: } \\
\text { Activity, Setting, Duration of } \\
\text { Exposure }\end{array}$ & $\begin{array}{l}\text { Attention } \\
\text { Measures }\end{array}$ \\
\hline $\begin{array}{l}\text { Hartig, } \\
1991\end{array}$ & $\begin{array}{l}\text { NonRan } \\
\text { domized } \\
\text { Crossov } \\
\text { er Trial }\end{array}$ & 68 & $\begin{array}{l}62 \% \text { Male } \\
35.9 \text { years (G1) } 29.2 \text { years } \\
(\mathrm{G} 2) \\
31.6 \text { years (G3) } \\
\text { Experienced Backpackers }\end{array}$ & $\begin{array}{l}\text { Wilderness backpacking vacation } \\
\text { Nonwilderness vacation } \\
\text { No vacation } \\
\text { 4-7 days (vacation groups) }\end{array}$ & Proofreading Task \\
\hline $\begin{array}{l}\text { Wu, } \\
2008\end{array}$ & $\begin{array}{l}\text { NonRan } \\
\text { domized } \\
\text { Crossov } \\
\text { er Trial }\end{array}$ & 23 & $\begin{array}{l}72 \% \text { Male } \\
\text { Schizophrenia Patients }\end{array}$ & $\begin{array}{l}\text { Horticulture activities } \\
\text { (indoor\&outdoor) } \\
\text { Regular hospital activities (indoor) } \\
\text { 90min/week x } 15 \text { classes }\end{array}$ & $\begin{array}{l}\text { Chu's Attention } \\
\text { Test }\end{array}$ \\
\hline $\begin{array}{l}\text { Ottosson, } \\
2005\end{array}$ & $\begin{array}{l}\text { NonRan } \\
\text { domized } \\
\text { Crossov } \\
\text { er Trial }\end{array}$ & 17 & $\begin{array}{l}87 \% \text { Female } \\
86 \text { years } \\
\text { Elderly Residents of the Care } \\
\text { Home }\end{array}$ & $\begin{array}{l}\text { Leisure time outside } \\
\text { (terrace\&garden) } \\
\text { Leisure time inside (room) } \\
\text { 1h Two sessions, } 14 \text { days apart }\end{array}$ & $\begin{array}{l}\text { DSB, DSF } \\
\text { NCT } \\
\text { SDMT }\end{array}$ \\
\hline $\begin{array}{l}\text { van den } \\
\text { Berg, } \\
2011\end{array}$ & $\begin{array}{l}\text { NonRan } \\
\text { domized } \\
\text { Crossov } \\
\text { er Trial }\end{array}$ & 12 & $\begin{array}{l}83 \% \text { Boys } \\
12.8 \text { years } \\
\text { Children Diagnosed with } \\
\text { ADHD }\end{array}$ & $\begin{array}{l}\text { Building a cabin, natural } \\
\text { (woodland) } \\
\text { Walking, urban (quiet } \\
\text { neighbourhood) } \\
\text { 1h Two activities, } 1 \text { day apart }\end{array}$ & $\begin{array}{l}\text { Test of Everday } \\
\text { Attention for } \\
\text { Children }\end{array}$ \\
\hline $\begin{array}{l}\text { Kuo, } \\
2001\end{array}$ & $\begin{array}{l}\text { Natural } \\
\text { Experim } \\
\text { ent }\end{array}$ & 145 & $\begin{array}{l}100 \% \text { Female } \\
34 \text { years } \\
\text { Heads of Households }\end{array}$ & $\begin{array}{l}\text { Living near high levels of } \\
\text { vegetation } \\
\text { Living near low levels of vegetation }\end{array}$ & DSB \\
\hline $\begin{array}{l}\text { Taylor, } \\
2002\end{array}$ & $\begin{array}{l}\text { Natural } \\
\text { Experim } \\
\text { ent }\end{array}$ & 169 & $\begin{array}{l}54 \% \text { Boys } \\
9.6 \text { years } \\
\text { Children }\end{array}$ & $\begin{array}{l}\text { High level of near-home nature } \\
\text { Low level of near-home nature } \\
\text { At least one year living in current } \\
\text { location }\end{array}$ & $\begin{array}{l}\text { DSB } \\
\text { Matching Familiar } \\
\text { Figures } \\
\text { NCT } \\
\text { SDMT } \\
\text { Stroop Test }\end{array}$ \\
\hline $\begin{array}{l}\text { Tennessen, } \\
1995\end{array}$ & $\begin{array}{l}\text { Natural } \\
\text { Experim } \\
\text { ent }\end{array}$ & 72 & $\begin{array}{l}42 \% \text { Male } \\
20 \text { years } \\
\text { Students }\end{array}$ & $\begin{array}{l}\text { All natural view from dormitory } \\
\text { Mostly natural view from dormitory } \\
\text { Mostly built view from dormitory } \\
\text { All built view from dormitory }\end{array}$ & $\begin{array}{l}\text { DSB, DSF } \\
\text { NCT } \\
\text { SDMT }\end{array}$ \\
\hline
\end{tabular}

(Ohly et al., 2016) 


\section{Curriculum Vitae}

Name: $\quad$ Corey Crossan

Post- $\quad$ Eastern Michigan University

secondary Ypsilanti, Michigan, United States

Education

and 2010-2014 B.Sc.

Degrees:

Honours and WGCA All-American Scholar Team 2013, 2014

Awards: $\quad$ Dean's Honour List, Eastern Michigan University 2010-2014

Eastern Michigan University National Scholar 2010-2014

Eastern Michigan University Recognition of Excellence 2010-2014

$\begin{array}{ll}\text { Related } & \text { Teaching Assistant } \\ \text { Work } & \text { The University of Western Ontario } \\ \text { Experience: } & \text { 2015-2017 }\end{array}$

\section{Publications:}

Crossan, M. \& Crossan, C. (2014). Leaders Should Learn to Engage the Moment Like Genie Bouchard. Huffington Post. 